\title{
Medievalista
}

Online

$30 \mid 2021$

Número 30

The Case of Bohemia and Austria, 1392-1555

\section{National Rivalry among Hospitallers?}

The Case of Bohemia and Austria, 1392-1555

Rivalidades nacionais entre Hospitalários? O Caso da Áustria e da Boémia, 1392-1555

\section{Karl Borchardt}

\section{(2) OpenEdition}

\section{Journals}

Electronic version

URL: https://journals.openedition.org/medievalista/4535

DOI: $10.4000 /$ medievalista.4535

ISSN: $1646-740 \mathrm{X}$

Publisher

Instituto de Estudos Medievais - FCSH-UNL

\section{Electronic reference}

Karl Borchardt, "National Rivalry among Hospitallers?", Medievalista [Online], 30 | 2021, Online since 01 July 2021, connection on 24 July 2021. URL: http://journals.openedition.org/medievalista/4535 ; DOI: https://doi.org/10.4000/medievalista.4535

This text was automatically generated on 24 July 2021.

\section{cc) (†)}

Mediavalista está licenciado com uma Licença Creative Commons - Atribuição-NãoComercial 4.0 Internacional. 
The Case of Bohemia and Austria, 1392-1555

National Rivalry among Hospitallers?

The Case of Bohemia and Austria, 1392-1555

Rivalidades nacionais entre Hospitalários? O Caso da Áustria e da Boémia, 1392-1555

\section{Karl Borchardt}

\section{EDITOR'S NOTE}

Data recepção do artigo / Received for publication: 1 de Dezembro de 2020

Data aceitação do artigo / Accepted in revised form: 18 de Março de 2021

Introduction

Quarrels and tensions among members of "international" military-religious orders during the Middle Ages have often been understood and explained by modern historians as "national" or "proto-national" rivalries. But methodologically two reservations should be made. Firstly, not many documents expressly mention ethnic or linguistic problems. And secondly, nations were not a dominant concept in medieval politics ${ }^{1}$. In the later Middle Ages, nations existed primarily "abroad", among merchants and craftsmen from distant regions ${ }^{2}$ and among students at universities far away from their homes ${ }^{3}$. Such nations were basically geographical; linguistic and ethnic homogeneity was not essential ${ }^{4}$. The councils of Pisa 1409, Constance 1414-1418, Siena 1423-1424 and - on a reduced scale - Basel 1431-1449 had nations such as Italia, Gallia, Germania, Anglia and Hispania, unsurprisingly as the councils included many university teachers ${ }^{5}$. At Constance in 1417, the 53 electors of Pope Martin V included 23 cardinals plus six delegates drawn from each of the five nationes ${ }^{6}$, and during the fifteenth century the cardinals were supposed to represent all nations of Christianity ${ }^{7}$. 
3 From the early fourteenth century the Hospitallers had seven langues or tongues at their central convent on Rhodes; after 1462 they had eight ${ }^{8}$. Their c.20 priories in Europe were grouped according to these tongues. But neither tongues nor priories - or grand priories, as they were called in early modern times $^{9}$ - were identical to nations or realms. Both Portugal and Castile on the one hand, and Bohemia and Austria on the other, illustrate this point. Until 1462, the two priories of Portugal and Castile-León were part of the Hispanic tongue; when it was split into two, Portugal and Castile-León together became one single new tongue, despite recurrent tensions and wars between the two realms. Bohemia, with its politically dependent regions of Moravia and Silesia, formed with Austria a single priory ${ }^{10}$. This remained so, despite recurrent tensions and wars between Austria and Bohemia, and despite the fact that many Hospitallers from Bohemia and Moravia spoke Czech, not German, as their native tongue. How far Romance languages on the Iberian Peninsula were mutually intelligible in the later Middle Ages, is a question beyond the scope of the present paper; German and Czech were definitely not. Nevertheless, Austria and Bohemia remained in one priory, as Castile and Portugal remained in one tongue.

4 The prior of Bohemia had a lieutenant for Austria who was called Meister or Statthalter and could have become a nucleus for Austrian independence from Bohemia. The priory had three further lieutenants, for Bohemia proper, for Moravia and for Silesia (Polonia) ${ }^{11}$. Moravia and Silesia were ruled by the Bohemian king and his court, which was comprised of princes, nobles and knights from all these regions. Austria was politically separate from the lands of the Bohemian crown. But Austria was not united, because there were two branches of the ruling Habsburg family with their own followers and networks, one in Austria proper and another one in Styria, Carinthia and Carniola. In Austria proper the two major Hospitaller centres were the strong castle at Mailberg ${ }^{12}$, c. 60 kilometres north of Vienna, and the commandery in the capital city of Vienna itself. In Styria the most important commandery was Fürstenfeld, c. 60 kilometres east of the capital town of Graz. Fürstenfeld had close connections with smaller houses such as Melling (c. 80 kilometres south-west of Fürstenfeld) and St. Peter in Carniola (c. 40 kilometres west of Triest). The Hospitaller lieutenant was styled as Meister or Statthalter ruling Austria, Styria, Carinthia and Carniola - Carinthia being a duchy as Austria and Styria ${ }^{13}$, and Carniola being a march that the Habsburgs called a duchy from 1364 onwards, although the Empire did not recognise this until 1590. The Hospitaller lieutenant for Austria, Styria, Carinthia and Carniola would usually govern key-commanderies such as Mailberg, Vienna (or at least the fortified house at Laa in the suburbs of Vienna) and Fürstenfeld. If he lacked the backing of both Habsburg lines at the same time, his influence was limited and his chances to obtain greater independence from Bohemia were not promising.

The document of 1392

6 In $1392 \mathrm{Fr}$. Johann Schenk ${ }^{14}$ was Lieutenant for Austria and Commander of Fürstenfeld, while Fr. Otto Lembucher was Commander of Mailberg. Their quarrel was discussed by Fr. Marcold von Wrutitz ${ }^{15}$, Prior of Bohemia from 1391 to 1397, and his provincial chapter at Eiwanowitz in Moravia on 13 February $1392^{16}$. Because few parallel cases are known in form and contents, the text of this charter is edited below as an appendix. The document was issued by a notary public who authenticated it with his handwriting and his signetum. But the charter also still bears 19 seals of Hospitallers who were present during the chapter. Similar documents were usually issued by the prior himself 
who chaired the chapter, together with some or all of the preceptors and other Hospitallers who were present ${ }^{17}$. The 1392 document deals with a complaint of Fr. Johann Schenk and three named Hospitallers against Fr. Otto Lembucher and other, unnamed Hospitallers who had the backing of Duke Albert III of the Austrian line of the Habsburg family, whose territories included Mailberg. The notary public describes, more or less verbatim, the formal complaint (plancta) and the decision (esguardium) which was found and pronounced during the chapter.

In the spring of $1391 \mathrm{Fr}$. Otto Lembucher had confiscated valuables, extorted payments and in a few cases incarcerated fellow-Hospitallers or their servants. His drastic measures against four commanders must have aroused public scandal, which contemporary chronicles ${ }^{18}$ appear to ignore. They do mention, however, a heavy tax that Albert III had imposed on ecclesiastical institutions in $1390^{19}$. Albert's purpose was to pay debts his late brother Leopold III, the founder of the Styrian line of the Habsburg family, had contracted for his wars against the Swiss over the allegiance of the town and territory of Lucerne. Against the Swiss Leopold had lost the battle and his life at Sempach in 1386. Thereafter, Albert assumed the regency for Leopold's four underage sons. In this context, the rich town of Vienna twice obtained a ducal privilege to the effect that no Viennese should be exempt from taxes, except the courtiers of the duke ${ }^{20}$. Neither of these two privileges said anything about tax exemption for Viennese clergy; it may have struck many as a good idea that the church should contribute. Albert III, however, lacked papal licence to tax ecclesiastical institutions, so Pope Boniface IX in Rome excommunicated him. Fearing that Albert might change sides and recognise Pope Clement VII in Avignon, whom Leopold III had recognised, Boniface soon withdrew his excommunication ${ }^{21}$. Yet in the spring of 1391, Fr. Otto Lembucher obviously had the backing of Albert III when he extorted payments from recalcitrant Hospitallers.

This becomes less surprising when we remember that Albert's chancellor Berthold von Wehingen $(\dagger 1410)^{22}$ was a brother of Lembucher's predecessor at Mailberg, Fr. Hugo von Wehingen. The Wehingen were knights from Swabia. Hugo the Elder had sold the family castle to Albert III's father Albert II in 1351, who had promised to look after his children in return. Thus Hugo the Younger became Commander of Hohenrain ${ }^{23}$, c. 20 kilometres north of Lucerne, and later on Commander of Mailberg ${ }^{24}$. On 22 March 1385, Albert III asked the Urbanist Hospitaller Master Fr. Riccardo Caracciolo to confirm Mailberg to Fr. Hugo for life ${ }^{25}$. The Duke's petition was granted at Cicciano, $35 \mathrm{~km}$ north-east of Naples, on 16 May 1385 by Fr. Riccardo and high-ranking Hospitaller brethren in his entourage ${ }^{26}$. At Genoa on 11 January 1386, Fr. Riccardo retained Fr. Hugo under his special jurisdiction ${ }^{27}$, an act that exempted Fr. Hugo personally together with his possessions from all other officers in the Hospital. In 1387 and 1389, Fr. Hugo was mentioned as Commander of Mailberg. Then he lost Mailberg to Fr. Otto Lembucher, contrary to his Magistral privilege of 1385. The reasons for this remain unclear. Certainly Fr. Hugo did not die, because from 1397 to 1405 he reappears, this time as Commander of Vienna and $\mathrm{Laa}^{28}$.

9 The monies Fr. Otto Lembucher extorted from his opponents in 1391 were considerable, amounting to 1215 florins and 221 pounds, some 1615.3 florins at a ratio of 1 florin for 132.5 pennies $^{29}$. They may have been paid ultimately to Duke Albert III. Further context for Fr. Otto Lembucher's actions might be the tense relations between Albert III and King Wenceslaus, the ruler of the Empire and of Bohemia, because the Prior Fr. Marcold von Wrutitz was a close counsellor of Wenceslaus ${ }^{30}$. In the early 1390s, Albert allied 
himself with two relatives, rivals and possible successors of the childless Wenceslaus, his brother King Sigismund of Hungary and his cousin Margrave Jobst of Moravia. One alliance against Wenceslaus dated from January $1392^{31}$, an earlier one from June $1390^{32}$. In the autumn of 1391 Wenceslaus tried to reconcile Albert ${ }^{33}$, but failed. In 1394 Wenceslaus was taken prisoner in Prague by Jobst. This led to open warfare in Bohemia and adjacent lands. In the end Wenceslaus had to be released from the strong castle of Wildberg in Austria where he had been confined, some 13 kilometres north of Linz ${ }^{34}$. Yet the compromise did not last. Before Duke Albert died in 1395, he had begun working for the deposition of Wenceslaus both as king of the Romans and as king of Bohemia.

10 Clearly in February 1392, the situation for the Hospitaller Prior of Bohemia was difficult enough. At Eiwanowitz, Fr. Marcold carefully avoided incriminating Albert III. He went as far as to claim that as a Czech noble he had difficulty dealing in German and asked another Hospitaller to act as his prolocutor. Nothing was said about the lawfulness of Fr. Lembucher's actions, as this might have provoked Duke Albert. It was stated only that the Commander of Mailberg had been legitimately summoned but had not come to Eiwanowitz. So he was declared disobedient and forfeited his office with its possessions. Conscientiously the chapter busied itself with a formal point and left the main issue open. In this way, they left the door open to further negotiations, especially since no successor was appointed for Fr. Otto Lembucher in Mailberg.

\section{Tensions between Austria and Styria} Hynko of Melling were not mentioned again after 1392, in contrast to Fr. Michael Sindram of Vienna, who was again attested in $1396^{35}$. Their adversary, Fr. Otto Lembucher, however, continued as commander of Mailberg until at least 1406, and his successor was a relative, Fr. Berhard Lembucher, who is attested in 1412 and 1419; in 1407 , Fr. Berhard had already been commander of Vienna ${ }^{36}$. As these developments show, the complaints of 1392 were counterproductive for most Hospitaller plaintiffs who afterwards disappeared. The defendant, however, survived; he must have had influential friends in Austria. Later on, in 1406, Fr. Otto Lembucher was part of an association of grand proprietors in Habsburg lands. Their alliance consisted of 22 towns, 81 nobles and 28 prelates plus two princes of the Empire, Berthold von Wehingen, Archbishop-Elect of Salzburg, who was at the same time Bishop of Freising, and Georg von Hohenlohe, Bishop of Passau. The allied proprietors mediated between the Austrian and Styrian lines of the Habsburg dynasty, Albert III's grandson Albert V on the one side and the two surviving sons of Leopold III, that is Leopold IV and Ernst I, on the other side. As Albert V was still a minor, Leopold IV assumed the regency for him in the Austrian lands and ceded his rights to his Styrian inheritance to his brother Ernst $\mathrm{I}^{37}$.

13 A complete list of the Hospitaller lieutenants for Austria, Styria, Carinthia and Carniola remains a desideratum. We know in $1423 \mathrm{Fr}$. Stephan Khodase, Commander of Fürstenfeld ${ }^{38}$, in $1468 \mathrm{Fr}$. Johann Kheser ${ }^{39}$, a former Commander of Fürstenfeld ${ }^{40}$, in 1473 Fr. Sebald Puchil ${ }^{41}$, and in $1494 \mathrm{Fr}$. Jakob Reinher, Commander of St. Peter in Carniola ${ }^{42}$. Fr. Johann Kheser was a priest brother, not a knight; in 1427 he had been Commander of Fürstenfeld, where in 1433 and 1438 he was succeeded by his relative Fr. Martin Kheser, while he himself was Commander of Vienna in 1430 and $1438^{43}$. The family names Khodase, Puchil and Reinher also point towards non-noble and even non- 
knightly descent, as was the rule for priest-brothers. This must have limited the political influence such lieutenants could exert. At any rate the important commanderies of Mailberg, Vienna and Fürstenfeld were not in one hand during these years, and the Habsburg dominions in Austria proper and in Styria were kept separate. One consequence was that the crisis of the Bohemian priory during the Hussite wars from 1419 to 1434 could not be used to secure greater independence for the Austrian lieutenant.

Meanwhile the important castle of Mailberg helped to defend Austrian independence against Styria. Duke Albert V, who ruled Austria, married the daughter of Emperor Sigismund ( $† 1437)$ and succeeded his father-in-law as King of the Romans, in Bohemia and in Hungary, but died young in 1439. At this time Albert's son Ladislaus was not yet born. Nicknamed the Posthumous, Ladislaus inherited Bohemia and Hungary, but the eldest member of the Styrian line, Duke Frederick V, was elected to the Empire in the same year - at first as King, and then from 1452 as Emperor Frederick III, married to Eleanor of Portugal - and took over the regency for Ladislaus. As long as he could, Frederick kept Ladislaus as his ward at court in Graz or Wiener Neustadt, which many leading politicians and landowners in Bohemia, Hungary and Austria resented. Prominent among the Austrian opposition was the Commander of Mailberg, Fr. Wilhelm Dachsner (zu Taxen). On 14 October 1451, he permitted Ulrich von Eitzing to bring together 250 friends at Mailberg who formed a confederation that was formally signed in December $1451^{44}$ and eventually forced Frederick III to release his ward in 1452. Ladislaus was escorted from Wiener Neustadt to Vienna where he established his court. With Ladislaus' sudden death in 1457, the male line of the Austrian branch of the Habsburg family became extinct. Bohemia and Hungary elected non-Habsburg kings. Frederick III assumed control of Austria, but he had to quarrel there against claims of his younger brother Albert VI ( $\dagger 1463)$ and against Ulrich von Eitzing ( $\dagger 1460)$, the political leader of the Austrian estates. Ulrich, his brothers and their followers, among them the Commander of Mailberg, supported Albert VI and fought against unification with Styria. In 1458, Albert VI took over the western part of Austria proper; in 1462, he besieged his brother in Vienna, and in 1463 he also conquered the eastern part of Austria with Vienna ${ }^{45}$. Stephan von Eitzing maintained good relations with the new Commander of Mailberg, Fr. Achaz Bohunko ${ }^{46}$; this person had been Frederick's candidate for Mailberg but supported him only when King George of Bohemia intervened on his behalf ${ }^{47}$. When Albert VI died on 2 December 1463 the Emperor's hold on Austria proper was no longer challenged by other members of the Habsburg family and he could turn his attention to Fr. Achaz Bohunko.

\section{The Emperor's Debts and St. George of Millstatt}

16 At this junction, the fate of Mailberg and the Hospitaller lieutenancy in Austria, Styria, Carithia and Carniola was bedevilled by two new factors: commanders who had loaned monies to the ruler of Austria, and Frederick III's plan to found his own militaryreligious order at Millstatt in Carinthia. Achaz Bohunko was the first but by no means the last commander at Mailberg who had made loans to Habsburg rulers. Still a layman, Bohunko served the Teutonic Order with mercenaries in Prussia when in 1454 war broke out there between the Highmaster on one side, the Prussian estates and Poland on the other side. The bankrupt Highmaster Fr. Ludwig von Ellrichshausen rewarded Achaz Bokunko with the Teutonic Order Commandery of Groß-Sonntag ${ }^{48}$ in Styria. As founders of Groß-Sonntag, both Emperor Frederick III and Count Ulrich of Schaunberg 
protested in 1455 that the commandery had been given to someone who was not a member of the Teutonic Order ${ }^{49}$. In 1457 Bohunko negotiated with the Emperor in Laibach $^{50}$ on behalf of the Teutonic Order. In 1458 he claimed 1,657 florins of Hungary from Groß-Sonntag, and the Teutonic Order Bailiff of Austria Fr. Johann von Pommersheim was licenced to pay this sum in three instalments ${ }^{51}$. In 1459 Bohunko gave Frederick III a loan of 2,000 florins of Hungary ${ }^{52}$. Later in that year, Bohunko supported Catholic Bohemian nobles - among them the Hospitaller Prior of Bohemia and the Emperor against George of Podiebrad, the Utraquist or former Hussite who had been elected king of Bohemia in $1458^{53}$.

The Bohemian prior accepted Bohunko as Commander of Mailberg on condition that he became a Hospitaller. Frederick III intervened on behalf of his creditor, as soon as the previous Commander, Fr. Wilhelm Dachsner, had died. As patron of Mailberg and Laa, and on behalf of all other dukes of Austria, Frederick III asked the prior to grant the two purportedly ever united houses to Bohunko. Afterwards the Prior Fr. Jodok von Rosenberg $^{54}$ appointed Bohunko to both Mailberg and Laa with estimated annual revenues of 25 marks of silver. On 10 January 1460, Pope Pius II agreed to this unusual appointment, but the papal charter was not issued until 1 April 1468 by Pope Paul II ${ }^{55}$. The long delay between approving the supplication and issuing the charter was not normal practice at the Roman curia. This point would merit closer inspection; at present it is advisable not to speculate about possible reasons.

At the same two dates, 10 January 1460 and 1 April 1468, the Emperor secured a papal decision that Mailberg and Laa should cease to be dependent upon the prior of Bohemia. Here again there is the problem of a long delay between supplication and charter. At any rate, in future the Commander of Mailberg, Fr. Achaz Bohunko, and his successors were to be dependent solely upon the Master on Rhodes. The document claimed that Mailberg and Laa had always been united and that both had been founded by previous dukes of Austria, who held the right to nominate or present the lieutenant:

“... quod preceptoria domorum castri Meurperg et in Laach invicem canonice unitarum et in ducatu Austrie consistentium Hospitalis sancti Iohannis Ierosolimitani Patauiensis diocesis per milites ex dicto ducatu oriundos et ipsi imperatori eiusque progenitoribus Austrie ducibus, qui pro tempore extiterunt et in quorum dominio domus ipse site sunt, fideles et gratos ad presentationem seu nominationem imperatoris et progenitorum predictorum generali locumtenenti magistri eiusdem Hospitalis in illis partibus pro tempore deputato factam per ipsum locumtenentem pro tempore institutos gubernari consueverant ...".

19 The text carefully avoided any hint that Mailberg used to have a lieutenant of the Prior of Bohemia (now resident at Strakonitz, a fortified castle to which the priors had moved from Prague during the times of the Hussite wars ${ }^{56}$ ), not of the Master of the Hospital (on Rhodes). Furthermore, it was questionable whether the duke really held a ius nominationis or presentationis and whether only the duke's subjects could be appointed as lieutenants. By papal decision, Mailberg was now freed from any subjection to Strakonitz. Moreover, Mailberg's commander was to be the superior of all Hospitallers in the dominions of the house of Austria:

“... ab omni superioritate et iurisdictione eiusdem preceptoris de Strakonitz tunc et pro tempore existentis auctoritate apostolica prorsus exemit et totaliter ac perpetuo liberavit nec non reliquias domos et preceptorias predictas in eiusdem ducatu, principatibus et dominiis hereditariis existentibus dicte preceptorie in Meurperg et in Laach ac eius pro tempore preceptori immediate subiecit illamque eis in caput constituit, iure tamen superioritatis et dominii, que magister dicti 
Hospitalis Rhodi super omnes preceptorias predictas habebat, in omnibus semper salvo ${ }^{57}$.

Then the Emperor argued that the master at Strakonitz, that is the prior of Bohemia, supported heresy. So on 22 July 1468 Paul II consented to the Emperor's supplication that Mailberg should be immediately subject to the Roman church, but the pope added a clause that reserved the rights of Master and Convent on Rhodes ${ }^{58}$. This was not what the Emperor wanted, and so far there is no trace that this papal charter was ever actually issued. In $1470 \mathrm{Fr}$. Achaz Bohunko acknowledged that Frederick III had given him Mailberg and Laa only until further notice ${ }^{59}$. The clause meant that after being repaid his monies, Fr. Bohunko would resign Mailberg and Laa, and the Emperor could then transfer them to St. George at Millstatt. This never happened, neither with Fr. Bohunko nor with his successors. One reason could be that Frederick III and his heirs never had enough money; thus Mailberg remained a Hospitaller castle.

Another reason was certainly that St. George at Millstatt turned out to be a failure. It has been argued that founding a new military-religious order was anachronistic in the fifteenth century, but this argument may be an oversimplification ${ }^{60}$. When Frederick travelled to Rome for a second time in the autumn of 1468 , the foundation made progress. The new order's centre was established in the extinct Benedictine monastery of St. George at Millstatt in Carinthia. Its first magister generalis became Hanns Siebenhirter $(\dagger 1508)^{61}$, who had been Frederick's Küchenmeister, responsible for the management and the monies of the imperial court. Any future master and other senior officers were to be appointed by Frederick III as the founder, and after him by any senior of the house of Austria. It has often been said that the ostensible purpose of the foundation was defence against Turkish raids from Bosnia through Croatia and Slavonia that threatened Carniola, Carinthia, Styria and Istria from the 1460s onwards. Yet no sources prove this ${ }^{62}$. The foundation charter issued by Pope Paul II on 1 January 1469 mentioned only the commemoration of Frederick III and his family ${ }^{63}$.

Frederick III surely also had political and socio-economic motives. His relations with nobles and knights in his dominions were complex and ambiguous; Achaz Bohunko was no exception here. Such nobles and knights wanted to serve their lord, but expected to be paid. Whenever Frederick was unable to pay, conflicts arose. One such conflict broke out in 1469, the year when St. George at Millstatt was established. Andreas Baumkircher, from a knightly family in the county of Görz $z^{64}$, had hired mercenaries and served both Ladislaus Posthumous and Frederick III in the 1450s and early 1460s. Because Frederick did not pay, he elected to help himself; in the Emperor's eyes, he "rose in rebellion." On 21 July 1469, Baumkircher won a resounding victory at Fürstenfeld, and protracted negotiations began after an armistice was declared. Finally, Baumkircher met the Emperor in Graz, but was treacherously taken prisoner and beheaded as a rebel on 23 April $1471^{65}$. The idea that the church should pay for the needs of the monarch or prince was not new, as we have seen in 1391/92. A militaryreligious order such as St. George of Millstatt endowed and dominated by the monarch was an obvious means to facilitate the ruler's access to ecclesiastical revenues.

Further motivations come to light when we look at Frederick's endowments for St. George at Millstatt more closely. The papal foundation charter mentioned

“... monasterium Milstat ac domum seu preceptoriam Morperch sancti Benedicti et sancti Iohannis Ierosolimitani ordinum Salczeburgensis et Patauiensis diocesum nec non hospitale sancti Martini Wyennensis monasterium nuncupatum eiusdem Patauiensis diocesis nec non capellam beate Marie Novefundationis ac 
parrochialem ecclesiam sancte Marie in Montestraden Salczeburgensis diocesis, que

de iure patronatus ipsius imperatoris existunt ..."66. bishop in Wiener Neustadt, because he held financial claims against the Emperor. Additionally, and similarly to the Bishop of Wiener Neustadt, he could not be forced to resign. Meanwhile political circumstances, especially growing tensions and finally open warfare between Frederick III and King Matthias Corvinus of Hungary from 1477 to 1490 , caused the situation to deteriorate. Following a treaty of $1463^{70}$, Frederick claimed that after Matthias' death he or his son Maximilian should accede to the throne of Hungary. When Matthias began to plan otherwise, Frederick allied himself with Matthias's enemy, King Vladislav of Bohemia, in 1477. Thereafter, in 1478, Matthias and Vladislav made peace with each other and partitioned the lands of the Bohemian crown; Bohemia proper stayed with Vladislav, while Moravia and Silesia went to Matthias. In consequence, Matthias was free to intensify his war against Frederick. Mailberg was an important place for both parties, and Pope sixtus IV tried not to estrange himself from either Frederick or Matthias, as he wanted both to fight against the Turks. Finding a successor for the aging Fr. Achaz Bohunko at Mailberg became a delicate problem in this context. In 1481 Bohunko appointed an imperial chamberlain Konrad Auer, who was not a Hospitaller, to administrate the commandery ${ }^{71}$. Auer was a creditor of the Emperor, as Bohunko had been in 1460. When paid, Auer was supposed to resign and Mailberg was to be effectively incorporated into St. George at Millstatt. On 1 October 1481, Frederick III instructed an envoy to negotiate this with Sixtus IV ${ }^{72}$.

Soon afterwards, Fr. Achaz Bohunko died. Subject to King Vladislav of Bohemia, an ally of Frederick's enemy Matthias, the Prior of Bohemia Fr. Johann von Schwanberg ${ }^{73}$ (r. 1472-1516) now appointed Fr. Georg Florstett as Bohunko's successor in Mailberg; 
Georg was to pay 100 florins of Hungary as annual responsions to the Order. Sixtus IV appointed three conservatores - the abbot of the Scots in Vienna, the provost of Klosterneuburg (in Austria, north of Vienna) and the provost of Maria Saal (in Carinthia) - for Georg on 11 December 1481 and issued a confirmation of the appointment on 31 January $1482^{74}$.

In 1483 Sixtus IV made two decisions, one for Frederick and for Matthias. Because in 1469 Pope Paul II had incorporated Mailberg into the Order of St. George, Sixtus ordered Konrad Auer to return Mailberg to the Emperor ${ }^{75}$. A few months later, Sixtus ordered Auer to return Mailberg to Fr. Johann von Schwanberg, Prior of Bohemia and Austria, as he was styled here, and to Fr. Georg Florstett; Cardinal Juan d'Aragonia, papal legate in Hungary, was to look into the case, Auer having appealed against a summons to court by Abbot Christoph of the Scots in Vienna ${ }^{76}$. In 1484 Innocent VIII decided in favour of Fr. Georg Florstett and renewed the subjugation of Mailberg to the priory of Bohemia ${ }^{77}$. From now on there were two rival commanders for Mailberg, one backed by the Habsburg court and one backed by the prior of Bohemia and the two allied, later united kingdoms of Bohemia and Hungary. Corvinus of Hungary conquered more and more of Austria, Styria and eastern Carinthia. Frederick III had to leave his favourite residences at Graz, Wiener Neustadt and Vienna ${ }^{78}$. Many Hospitallers resented the imperial appointment of a nonHospitaller. Even Auer's procurator at Mailberg, Fr. Kaspar Haugwitz, together with certain unnamed commanders, wanted to elect a new master. Auer, still not a Hospitaller, obtained an imperial mandate that no such election was permitted. He insisted that he was the lawful successor of Fr. Achaz Bohunko as Master of Mailberg and as Lieutenant of the Bohemian prior for Austria, Styria, Carinthia and Carniola. But he promised not to alienate Mailberg from the Hospital. As soon as Frederick III ordered it, he would follow the papal mandate ${ }^{79}$; this meant that as soon as he had got back his monies he would resign Mailberg and the commandery would be effectively incorporated into St. George at Millstatt. Mailberg, however, remained under the de facto control of Matthias until 1490. In 1486 Florstett acted as Master of Mailberg, Commander of Vienna and Brünn, and a certain Johann Landsberg was his procurator ${ }^{80}$.

Contrary to what one might expect, the extraordinary situation at Mailberg outlived Hungarian rule in Austria by decades. Matthias died in Vienna on 6 April 1490, without leaving a legitimate heir. On 15 July 1490, the Hungarians elected King Vladislav of Bohemia to be their next ruler. The Emperor himself had been a candidate. But he had to be content with the reconquest of those parts of Austria, Styria and Carinthia that Matthias had occupied. Frederick's son Maximilian led the operations. On 7 November 1491, Frederick and Vladislav concluded a peace treaty ${ }^{81}$. After the reconquest, Maximilian installed a procurator (Pfleger) at Mailberg, in 1494 Friedrich von Weissing ${ }^{82}$, in 1495 Niclas Pflug ${ }^{83}$. The commandery as such he pawned away to the heirs of Ulrich I von Grafenegg ( $\uparrow 1487)$, another entrepreneur in mercenaries, not unlike Achaz Bohunko, who had held claims against Frederick III ( $\dagger 1493)$. The prior of Bohemia accepted that. In 1494 the Supreme Chancellor of Bohemia, Johann von Schellenberg, agreed that Mailberg should go to the Hospitaller Fr. Andreas von Grafenegg, one of Ulrich I's sons ${ }^{84}$. In 1496 Maximilian's governors in Vienna ordered Andreas Schortt, who may have been Maximilian's procurator at Mailberg, to hand 
over the castle with all documents and appurtenances to Johann von Grafenegg85; Johann represented his carnal brother Fr. Andreas. In $1503 \mathrm{Fr}$. Andreas died in battle, at a hitherto unknown place. Meeting Maximilian at Linz, Wok von Rosenberg86 and Fr. Johann von Schwanberg obtained a promise that Maximilian would not take away Mailberg from the Hospitallers; in return they agreed on behalf of the priory of Bohemia that Maximilian should choose the next commander at Mailberg, either Fr. Johann von Schwanberg or another Hospitaller ${ }^{87}$.

But again Maximilian pawned away Mailberg, this time for 7,000 florins of the Rhine to Johann Maraxi von Naschkau ${ }^{88}$. The brothers Hans and Ulrich II von Grafenegg were asked to return Mailberg to Maximilian who in turn would pay them annually 350 florins of the Rhine in Vienna ${ }^{89}$. This arrangement was thwarted by Ulrich II von Grafenegg, who became a Hospitaller and thereby enlisted the help of the Prior of Bohemia, who was to receive 3,000 of his 7,000 florins. Johann Maraxi was promised other revenues, and Mailberg was handed over to Ulrich II $^{90}$. The Grafenegg brothers, first Andreas and then Ulrich II, became Hospitallers more or less only to safeguard their financial claims. In this way they resembled Achaz Bohunko, whereas Konrad Auer had refused to become a Hospitaller at all. Fr. Ulrich II von Grafenegg kept Mailberg until his death in 1505 or 1506. From 1509 until at least $1512^{91}$ the next Master of Mailberg was Peter Maraxi, a cousin of Johann Maraxi ${ }^{92}$. The Hospitallers on Rhodes held Peter Maraxi to be an illegal intruder; in 1512 the Master Fr. Emery d'Amboise and the Convent on Rhodes gave Mailberg for ten years to Fr. Christoph Waldner, Preceptor of Torlesen in the Priory of Bohemia ${ }^{93}$, who apparently served on Rhodes.

A comprehensive and final compromise between Habsburg and the Jagiellonian rulers was reached in 1515 between Emperor Maximilian ( $\dagger 1519)$ and the two Jagiellonian kings Vladislav of Hungary ( $\uparrow 1516)$ and Bohemia and Sigismund of Poland ( $\dagger 1548)$, who was also Grand Duke of Lithuania. The Emperor promised to mediate between the Teutonic Order in Prussia and Poland and to withdraw his support for Grand Duke Vasili III of Moscow. In return Vladislav's son and heir Louis II married the Emperor's granddaughter Mary, whereas Mary's brother Ferdinand married Vladislav's daughter Anne ${ }^{94}$. Negotiations about Mailberg followed. In 1517 Maximilian returned Mailberg to the Bohemian priory, but Maximilian's confessor, Dr Philipp Flachberger, became the prior's lieutenant for Austria, Styria, Carinthia and Carniola. The Commander of Mailberg remained the prior's candidate, Fr. Hinko Popel von Lobkowitz, son of the Supreme Chancellor of Bohemia, who died in 1520. He was succeeded by Fr. Christoph Waldner, the Rhodian candidate of 1512, who served on Rhodes and fell during the siege of 1522. Already in 1521 Mailberg was promised to Fr. Reinprecht von Ebersdorf, a knight from Austria ${ }^{95}$.

When King Louis II of Hungary and Bohemia fell against the Ottomans at Mohacs on 29 August 1526, without leaving a child from his marriage, Archduke Ferdinand ( $†$ 1564) and his wife Anne secured succession to the thrones of Hungary and Bohemia. Although southern and eastern parts of Hungary were lost to the Turks and to Hungarian aristocrats such as John Zápolya, Mailberg was now surrounded by Habsburg dominions from all sides. From 1526 to 1531, its commander was Fr. Joseph Kölderer, a relative of Jörg Kölderer ( $\uparrow 1540)$, who had served at Maximilian's court in Innsbruck as a painter and an architect since the late 1490s. It seems that Fr. Joseph Kölderer was the last contentious commander at Mailberg. It is not unlikely that his appointment had financial aspects similar to the previous appointments for Bohunko, Auer, Grafenegg 
and Maraxi. The finances of the Habsburg rulers are essential for understanding what was going on at Mailberg. Unfortunately, the state of research on this topic is not yet advanced enough to arrive at definitive conclusions ${ }^{96}$. At any rate, from 1533 to his death in 1555 Joseph's successor was Fr. Reinprecht von Ebersdorf, who also administered the commanderies of Vienna and Laa, Striegau and Breslau, the latter two in Silesia. Contrary to his predecessors at Mailberg, he was from a very renowned knightly family that held the hereditary office of chamberlain (Erbkämmerer) in the duchy of Austria. Fr. Reinprecht was a military leader. In 1529 he helped to defend Vienna when the Turks besieged it, and in 1532 he distinguished himself against the Turks near Wiener Neustadt. Fr. Reinprecht died on 10 January $1554^{97}$.

From 1526 onwards, Mailberg's subjugation to the Bohemian priory was welcomed at the Habsburg court as a means of furthering the integration of their dominions that now stretched from Silesia to the Adriatic. There were no longer political, social or economic reasons to contemplate separating Mailberg in particular or the Austrian Hospitallers in general from the priory of Bohemia. It was primarily honorific when, in 1555 , the Grand Prior of Bohemia Fr. Zbinko Berka von Dauba und Leipa ${ }^{98}$ granted to Fr. Ludwig von Bollweiler, priest-brother of knightly descent and ambassador of the Grand Master Fr. Claude de la Sengle to Emperor Ferdinand I ( $† 1564)$ in Vienna, the traditional title of Lieutenant for Austria, Styria, Carinthia and Carniola; following tradition, however, Fr. Ludwig also became Commander of Mailberg, Vienna, Fürstenfeld and Melling ${ }^{99}$. This emphasises that great weight of history in the Hospital of St. John.

\section{Conclusions}

The medieval Hospitaller priory of Bohemia was riven by ethnic divisions and mutually unintelligible languages. The prior's Lieutenant for Austria, Styria, Carinthia and Carniola could have been a nucleus for independence from Bohemia. But it would be inadequate and misleading to explain its history as being conditioned by national rivalries. Political and socio-economic forces were more influential. In 1392 the provincial chapter under the Prior Fr. Marcold von Wrutitz had good political reasons not to quarrel with Duke Albert III of Austria. Rivalry between the two Habsburg lines in Austria proper and in Styria made it almost impossible to grant to the lieutenant the two important commanderies of Mailberg and of Fürstenfeld at the same time, a fact that weakened the lieutenant's position considerably. So the Hussite wars from 1419 to 1434 were not exploited as an opportunity for separation. From c.1460 onwards, when Austria and Styria were again united, Mailberg came into the possession of knights who had been mercenary leaders and other creditors of Emperor Frederick III and his son Maximilian. With papal help, Frederick III obtained both the separation of Mailberg from Bohemia in 1468, and in 1469 its incorporation into his own, newly founded military-religious Order of St. George at Millstatt in Carinthia. But the Habsburg rulers were apparently unable to repay their creditors. This thwarted both the separation and the incorporation. For political reasons, Maximilian sometimes promised to accept appointments to Mailberg made by the Bohemian prior who had the backing of the realms of Bohemia and Hungary. In the later Middle Ages commanders of Mailberg came from up to four partially overlapping networks, from knightly families in Austria, from the Habsburg courts (Bohunko, Auer, Grafenegg, Maraxi, Kölderer), from the Bohemian priory (Popel von Lobkowitz) and from Rhodes (Waldner). The Hospitaller prosopography merits further studies, not only in Austria and Bohemia ${ }^{100}$. In 1526 
Ferdinand I of Austria took over both realms. To separate Austria from the rest of the priory seemed no longer necessary; on the contrary, it might have been counterproductive, as the large priory helped to hold together the Habsburg dominions from Silesia in the north to Carniola in the south. Only in 1938, twenty years after the demise of the Habsburg monarchy, did Austria become a grand priory of its own, separate from the grand priory of Bohemia ${ }^{101}$.

\section{BIBLIOGRAPHY}

\section{Manuscript sources}

Prague, Národní archiv, Maltézští rytíři - české velkopřevorství, ns. 951, 1465, 1479, 1489, 1496, 1653, 2093, 2097, 3097 [charters in Prague available at https://www.monasterium.net/mom/CZNA/RM/fond].

Printed sources

Archiv für österreichische Geschichte 1 (1848).

BORCHARDT. Karl (ed.) - Documents Concerning Central Europe from the Hospital's Rhodian Archives, 1314-1428. Abingdon-New York: Routledge, 2020 (The Military Religious Orders: History, Sources and Memory).

HLAVÁČEK, Ivan; HLEDÍKOVÁ, Zdeňka (eds.) - Nichtbohemikale mittelalterliche Originalurkunden in den böhmischen Ländern. Köln-Wien: Böhlau-Verlag, 1977 (Archiv und Wissenschaft 1).

KRAUS, Thomas R. - "Eine unbekannte Quelle zur ersten Gefangenschaft König Wenzels im Jahre 1394". Deutsches Archiv zur Erforschung des Mittelalters 43 (1987), pp. 135-195.

LACKNER, Christian - Ein Rechnungsbuch Herzog Albrechts III. von Österreich. Edition und Textanalyse. Wien: Selbstverlag des NÖ Instituts für Landeskunde, 1996 (Studien und Forschungen aus dem Niederösterreichischen Institut für Landeskunde 23).

LÜNIG, Johann Christian (ed.) - Codex Germaniae diplomaticus. Vol. 1. Frankfurt /Main: Bey Friedrich Lanckischens Erben, 1732.

Materialien zur österreichischen Geschichte. Aus Archiven und Bibliotheken. Ed. Joseph Chmel, vol. 2. Wien: Peter Rohrmann, 1840.

MOCHTY-WELTIN, Christina - "Inventarium der Eitzingerischen brieff in der grossen truhen liegendt". NÖLA Mitteilungen aus dem Niederösterreichischen Landesarchiv 15 (2012), pp. 212-263; p. 17 (2016), pp. 178-369.

Monumenta Ducatus Carinthiae. Ed. Hermann Wiessner, vol. 11: Die Kärntner Geschichtsquellen 1414-1500. Klagenfurt, 1972.

Regesta chronologico-diplomatica Friderici III Romanorum Imperatoris (Regis IV). Ed. Joseph Chmel. Wien: Peter Rohrmann, 1840. 
Regesta Habsburgica. Regesten der Grafen von Habsburg und der Herzoge von Österreich aus dem Hause Habsburg, V. Abteilung: Die Regesten der Herzoge von Österreich 1365-1395, 2. Teilband (1371-1375). Ed. Christian Lackner in collaboration with Claudia Feller and Stefan Seitschek. Wien-München: Böhlau, 2010.

Regesta Imperii XIII, 24 (ns. 206-207), 26 (ns. 663, 716); XIV, 1 (n. 1326); XIV, 2 (n. 7187); XIV, 4, 1 (ns. 17911, 17933, 17934, 17936, 17942, 18471, 18562, 18861, 19489); XIV, 4,2 (n. 20525) [Available at http://www.regesta-imperii.de/regesten/suche.html].

Regesten Kaiser Friedrichs III. (1440-1493): nach Archiven und Bibliotheken geordnet H. 30. Ed. Peter Gretzel. Wien-Köln-Weimar: Böhlau, 2014.

Repertorium Germanicum IX: Verzeichnis der in den Registern und Kameralakten Pauls II. vorkommenden Personen, Kirchen und Orte des Deutschen Reiches, seiner Diözesen und Territorien, 1464-1471. Tübingen: Max Niemeyer Verlag, 2000.

Repertorium Germanicum X: Verzeichnis der in den Registern und Kameralakten Sixtus' IV. vorkommenden Personen, Kirchen und Orte des Deutschen Reiches, seiner Diözesen und Territorien 14711484. Berlin-Boston: De Gruyter, 2018.

SCHWIND, Ernst Freiherr; DOPSCH, Alphons (eds.) - Ausgewählte Urkunden zur VerfassungsGeschichte der deutsch-österreichischen Erblande im Mittelalter. Innsbruck: Wagner, 1895.

SENCKENBERG, Heinrich Christian (ed.) - Selecta iuris et historiarum tum anecdota tum iam edita, sed rariora, IV/2. Frankfurt am Main, 1738.

“Wiener Annalen von 1348-1404". in SEEMÜLLER, Joseph (ed) - Österreichische Chronik von den 95 Herrschaften. Hannover: Hahn 1909, pp. 231-242.

Studies

Andreas Baumkircher und seine Zeit, ed. Burgenländisches Landesmuseum. Eisenstadt, 1983 (Wissenschaftliche Arbeiten aus dem Burgenland 67).

BACHMANN, Adolf - Deutsche Reichsgeschichte im Zeitalter Friedrichs III. und Max I. vol. 1, Leipzig, 1884.

BEUMANN, Helmut; SCHRÖDER, Werner (eds.) - Nationes. Historische und philologische Untersuchungen zur Entstehung der europäischen Nationen im Mittelalter, 9 vols. Sigmaringen: Th. Verlag, 1978-1991.

BONNEAUD, Pierre - Le prieuré de Catalogne, le couvent de Rhodes et la couronne d'Aragon: 1415-1447. Millau: Conservatoire Larzac, 2004 (Milites Christi 2).

BONNEAUD, Pierre - Els hospitalers catalans a la fi de l'edat mitjana: l'orde de l'Hospital a Catalunya i a la Mediterrània, 1396-1472. Lleida: Pagès, 2008 (Els ordes militars 11).

BORCHARDT, Karl - "Hospitaller chapters in the medieval priory of Alamania". in MORTON, Nicholas (ed.) - Piety, Pugnacity and Property. Vol. 7. The Military Orders. Abingdon-New York: Routledge, 2020, pp. 195-207.

BOULTON, D'Arcy Jonathan Dacre - The Knights of the Crown. The Monarchical Orders of Knighthood in Later Medieval Europe 1325-1520. Woodbridge: Boydell 1987.

BRANDMÜLLER, Walter - Das Konzil von Pavia-Siena 1423-1424. Paderborn: Ferdinand Schoningh, 2002 (Konziliengeschichte A 18). 
BUES, Almut; REXHEUSER, Rex (eds.) - Mittelalterliche nationes, neuzeitliche Nationen. Probleme der Nationenbildung in Europa. Wiesbaden: Harrassowitz, 1995 (Deutsches Historisches Institut, Warschau, Quellen und Studien 2)

BUTTLAR-GERHARTL, Gertrud - "Der St. Georgs-Ritterorden und Wiener Neustadt". in NIKOLASCH, Franz (ed.) - Studien zur Geschichte von Millstatt und Kärnten, Vorträge der Millstätter Symposien 1981 bis 1995. Klagenfurt: Habelt, 1997 (Archiv für vaterländische Geschichte und Topographie 78), pp. 511-527.

CSENDES, Peter; OPLL, Ferdinand (eds.) - Wien. Geschichte einer Stadt. Vol. 1. Von den Anfängen bis zur ersten Wiener Türkenbelagerung (1529). Wien: Böhlau, 2001.

DAUBER, Robert L. - Die Johanniter-Malteser Orden in Österreich und Mitteleuropa. 850 Jahre gemeinsamer Geschichte, vol. 2: Spätmittelalter und frühe Neuzeit (1291 bis 1618). Wien: [private printing], 1998.

DAUBER, Robert L. - Die Johanniter-Malteser Orden in Österreich und Mitteleuropa. 850 Jahre gemeinsamer Geschichte. Vol. 3: Neue Zeit (1618 bis 1798). Wien: [private printing], 1998.

DELAVILLE LE ROULX, Joseph - Les Hospitaliers à Rhodes jusqu'à la mort de Philibert de Naillac (1310-1421). Paris: Leroux, 1913.

DEMEL, Bernhard - "Zur Geschichte der Johanniter und des Deutschen Ordens in Kärnten". in NIKOLASCH, Franz (ed.) - Studien zur Geschichte von Millstatt und Kärnten, Vorträge der Millstätter Symposien 1981 bis 1995. Klagenfurt: Habelt, 1997 (Archiv für vaterländische Geschichte und Topographie 78), pp. 787-826.

DENDORFER, Jürgen - "Wer wird Kardinal? Kardinalskarrieren und die Zusammensetzung des Kollegs (1417-1471)”. in DENDORFER, Jürgen; LÜTZELSCHWAB, Ralf - Geschichte des Kardinalats im Mittelalter. Stuttgart: Anton Hiersemann, 2011 (Päpste und Papsttum 39), pp. 361-372.

FILIP, Václav; BORCHARDT, Karl - Schlesien, Georg von Podiebrad und die römische Kurie. Würzburg: Verein für Geschichte Schlesiens, 2005 (Wissenschaftliche Schriften des Vereins für Geschichte Schlesiens 6).

FINKE, Heinrich - "Die Nation in den spätmittelalterlichen Konzilien”. Historisches Jahrbuch 57 (1937), pp. 323-338. Reprint in BÄUMER, Remigius (ed.) - Die Entwicklung des Konziliarismus. Werden und Nachwirken der konziliaren Idee. Darmstadt: Wissenschaftliche Buchgesellschaft, 1976 (Wege der Forschung 279), pp. 347-368.

FROMME, Bernhard - "Die Wahl des Papstes Martin V". Römische Quartalschrift für christliche Altertumskunde und Kirchengeschichte 10 (1896), pp. 133-162.

FÜRNKRANZ, Rudolf (ed.) - Mailberg. Ein Abriß der Ortsgeschichte. Festschrift anläßlich der Verleihung des Marktwappens durch die Landesregierung am 23. Oktober 1999. Mailberg, 1999.

Geschichte des Benedictiner-Stiftes Melk in Niederösterreich, seiner Besitzungen und Umgebungen 2/2. Wien: Beck, 1869.

GUTKAS, Karl - "Der Mailberger Bund von 1451. Studien zum Verhältnis von Landesfürst und Ständen um die Mitte des 15. Jahrhunderts". Mitteilungen des Instituts für Österreichische Geschichtsforschung 74 (1966), pp. 51-94, 347-392.

GUTKAS, Karl - Geschichte des Landes Niederösterreichs, 4th ed. St. Pölten-Wien: NÖ Pressehaus, 1984.

HEINIG, Paul-Joachim - Kaiser Friedrich III. (1440-1493). Hof, Regierung, Politik. 3 vols., Köln-WeimarWien: Böhlau, 1997 (Forschungen zur Kaiser- und Papstgeschichte des Mittelalters 17). 
HELMRATH, Johannes - Das Basler Konzil 1431-1449. Forschungsstand und Probleme. Köln: Böhlau, 1987 (Kölner Historische Abhandlungen 32).

HERNANDO SÁNCHEZ, Carlos José (ed.) - Roma y España, un crisol de la cultura europea en la Edad Moderna. Actas del Congreso Internacional celebrado en la Real Academia de España en Roma del 8 al 12 de mayo de 2007. Madrid: Sociedad Estatal para la Acción Cultural Exterior, 2007.

HOENSCH, Jörg K. - Matthias Corvinus. Diplomat, Feldherr und Mäzen. Graz-Wien-Köln: Styria, 1998.

HUNYADI, Zsolt - "The Western Schism and Hungary: From Louis I to Sigismund of Luxembourg”. Chronica 13 (2017), pp. 45-53.

JAN, Libor - "Ivanovice na Hané, Orlovice a johanitský řád (Příspěvek k poznání struktury a ekonomiky rytířských duchovních řádů do konce 15. století)”. Časopis Matice Moravské 111 (1992), pp. 199-226.

JAN, Libor - "Die Entwicklung des böhmischen Priorats der Johanniter". in BORCHARDT, Karl; JAN, Libor (eds.) - Die Geistlichen Ritterorden in Mitteleuropa: Mittelalter. Brno: Matice moravská, 2011 (Země e kultura ve střední Evropě 20), pp. 79-98.

JANKO, Wilhelm Edler von - "Ebersdorf, Reinprecht von". Allgemeine Deutsche Biographie [Online] 5 (1877), pp. 578-579 [accessed at 25 November 2020]. Available at: https://www.deutschebiographie.de/pnd13573522X.html.

KAPP, Daniel - "Der Orden von 1938 bis 1945: Zwischen Anpassung auf Auflösung”. in STEEB, Christian; STRIMITZER, Birgit (eds.) - Der Souveräne Malteser-Ritter-Orden in Österreich. Graz: Leykam 1999, pp. 241-249.

KIBRE, Pearl - The Nations in the Medieval Universities. Cambridge/Mass.: Mediaeval Academy of America, 1948 (The Mediaeval Academy of America, 49).

KOTLÁROVÁ, Simona - Jan III. z Rožmberka: 1484 - 1532: generální převor johanitského řádu $v$ Čechách a vladař rožmberského domu. Vyd. 1. České Budějovice: Veduta, 2010 (Osobnosti českých a moravských dějin, 9).

KROPF, Rudolf (ed.) - Andreas Baumkircher. Leben und Sterben im 15. Jahrhundert. Eisenstadt: Burgenländischen Landesregierung, 2013 (Wissenschaftliche Arbeiten aus dem Burgenland 144).

KROPF, Rudolf; POLSTER, Gert (eds.) - Andreas Baumkircher und das ausgehende Mittelalter. Tagungsband der 32. Schlaininger Gespräche 16. bis 20. September 2012. Eisenstadt: Landesmuseum, 2015.

KURZ, Franz - Österreich unter Herzog Albrecht III., 2 vols. Linz: Haslinger, 1827.

LACKNER, Christian - Hof und Herrschaft: Rat, Kanzlei und Regierung der österreichischen Herzoge (1365-1406). Wien-München: Oldenbourg, 2002 (Mitteilungen des Instituts für Österreichische Geschichtsforschung, Ergänzungsband 41).

LANGMAIER, Konstantin Moritz - A. Erzherzog Albrecht VI. von Österreich (1418-1463). Ein Fürst im Spannungsfeld von Dynastie, Regionen und Reich. Köln: Böhlau, 2015 (Forschungen zur Kaiser- und Papstgeschichte des Mittelalters 38).

LATZKE, Wilhelm - "Die Klosterarchive". in BITTNER, Ludwig (ed.) - Gesamtinventar des Wiener Haus-, Hof- und Staatsarchivs, Teil 3, ed. Wien, 1938, pp. 583-616.

LECHNER, Karl - "Die Kommende Mailberg”. in WIENAND, Adam - Der Johanniter-Orden. Köln: Wienand-Verlag, 1970, pp. 413-425.

LUTTRELL, Anthony - "The Hospitaller Province of Alamania to 1428”. in NOWAK, Zenon Hubert (ed) - Ritterorden und Region - politische, soziale und wirtschaftliche Verbindungen im Mittelalter, Torun: 
Uniw. Mikołaja Kopernika, 1995 (Ordines Militares. Colloquia Torunensia Historica 8), pp. 21-41. Reprint in The Hospitaller State on Rhodes and its western Provinces, 1306-1462. Aldershot: Ashgate, 1999 (Variorum Collected Studies Series 655), n. XII.

MEYER, Carla - "Eliten des Hofes - Eliten der Stadt. Ständische Verhaltenskonzepte und gesellschaftliche Identitätsbildung im Reflex der Literatur um Herzog Albrecht III. von Habsburg (1365-1395)". in PARAVICINI, Werner; WETTLAUFER, Jörg (eds.) - Der Hof und die Stadt. Konfrontation, Koexistenz und Integration in Spätmittelalter und früher Neuzeit. 9. Symposium der Residenzen-Kommission, Halle an der Saale, 25.-28. September 2004. Ostfildern: Th. Verlag, 2006, pp. 449-470.

MITÁČEK, Jiřri - “Strakonice ve struktuře Cěské provincie řadu johanitů za vlády Lucemburků". Jihočeský Sborník Historický 75 (2006), pp. 40-61.

MITÁČEK, Jiřri - "Die böhmische Provinz des Johanniterordens und die Luxemburger 1310-1437". in BORCHARDT, Karl; JAN, Libor - Die geistlichen Ritterorden in Mitteleuropa, Mittelalter. Brno: Matice moravská, 2011 (Země e kultura ve střední Evropě 20), pp. 99-113.

MITIS, Oskar von - "Die schwäbischen Herren von Wehingen in Österreich - ein Beispiel für Familienwanderung im Mittelalter". Jahrbuch für Landeskunde von Niederösterreich. Ser. NF, 23 (1930), pp. 76-92.

MÜHLBERGER, Kurt - “Relikte aus dem Mittelalter: Die ‘Akademischen Nationen' im Rahmen der neuzeitlichen Universitätsgeschichte. Mit einem Exkurs zur Natio Hungarica Universitatis Vindobonensis". in LENGYEl, Zsolt K. (ed.) - Österreichisch-ungarische Beziehungen auf dem Gebiet des Hochschulwesens / Osztrák-magyar felsőoktatási kapcsolatok. Székesfehérvár-Budapest: Kodolányi János Főiskola - Eötvös Loránd Tudományegyetem Könyvtára, 2010, pp. 11-32.

NEHRING, Karl - Matthias Corvinus, Kaiser Friedrich III. und das Reich. Zum hunyadisch-habsburgischen Gegensatz im Donauraum. München: R. Oldenbourg, 1975 (Südosteuropäische Arbeiten 72).

NIEDERSTÄTTER, Alois - Die Herrschaft Österreich. Fürst und Land im Spätmittelalter. Wien: Ueberreuter, 2001 (Österreichische Geschichte 1278-1411, ed. Herwig Wolfram).

PETERS, Henriette - Ein Formelbuch aus der Kanzlei Albrechts V, unpublished paper from the Institut für Österreichische Geschichtsforschung. Wien, 1956.

PETERSOHN, Jürgen - “... quod sanctitas sua in auxilium brachii secularis maiestati sue firmiter adhereat. Politische Zielvorstellungen Kaiser Friedrichs III. für ein Hilfsbündnis mit Papst Sixtus IV". in FUCHS, Franz; HEINIG, Paul-Joachim; SCHWARZ, Jörg - König, Fürsten und Reich im 15. Jahrhundert. Köln: Böhlau, 2009 (Forschungen zur Kaiser- und Papstgeschichte des Mittelalters, Beihefte zu J. F. Böhmer, Regesta Imperii 29), pp. 123-141.

PETTI BALBI, Giovanna - Mercanti e nationes nelle Fiandre: i genovesi in età bassomedievale. Pisa: ETS, 1996 (Piccola biblioteca Gisem 7).

PETTI BALBI, Giovanna (ed.) - Comunità forestiere e "nationes" nell'Europa dei secoli XIII-XVI, Napoli: Liguori Ed., 2001(Europa mediterranea. Quaderni 19).

PINI, Antonio Ivan - "Le 'nationes' studentesche nel modello universitario bolognese del Medioevo". in BRIZZI, Gian Paolo; ROMANO, Andrea (eds.) - Studenti e dottori nelle università italiane (origine-XX secolo). Atti del Convegno di studi (Bologna, 25-27 novembre 1999). Bologna: Clueb, 2000, pp. 21-29.

PRIBRAM, Albert Francis - Materialien zur Geschichte der Preise und Löhne in Österreich 1. Wien: Carl Ueberreuter, 1938. 
RÁzSÓ, Gyula - Die Feldzüge des Königs Matthias Corvinus in Niederösterreich 1477-1490. $3^{\text {rd }}$ ed. Wien: Österreichischer Bundesverlag, 1982 (Militärhistorische Schriftenreihe 24).

SARNOWSKY, Jürgen - Macht und Herrschaft im Johanniterorden des 15. Jahrhunderts. Verfassung und Verwaltung der Johanniter auf Rhodos (1421-1522). Münster/Westfalen: LIT, 2001(Vita regularis 14).

SCHNEIDER, Christian - "Eliten des Hofes - Eliten der Stadt. Ständische Verhaltenskonzepte und gesellschaftliche Identitätsbildung im Reflex der Literatur um Herzog Albrecht III. von Habsburg (1365-1395)". in PARAVICINI, Werner; WETTLAUFER, Jörg (eds.) - Der Hof und die Stadt. Konfrontation, Koexistenz und Integration in Spätmittelalter und früher Neuzeit. 9. Symposium der Residenzen-Kommission, Halle an der Saale, 25.-28. September 2004. Ostfildern: Th. Verlag, 2006, pp. 449-470.

SCHNEIDER, Christian - "Höfische Lebensform und gesellschaftliche Identität. Literarische Texte um Herzog Albrecht III. von Österreich”. in DARTMANN, Christoph; MEYER, Carla - Identität und Krise? Zur Deutung vormoderner Selbst-, Welt- und Fremderfahrungen. Münster/Westfalen: Rhema, 2007, pp. 85-95.

SPUFFORD, Peter - Handbook of Medieval Exchange. London: Royal Historical Society, 1986 (Royal Historical Society, Guides and Handbooks 13).

ŠTĚPÁN, Václav - Moravsky markrabě Jošt (1354-1411). Brno: Matice moravská, 2002 (Kniznice Matice Moravské 10).

STIERLE, Leopold - Die Herren von Wehingen. Ein schwäbisches Rittergeschlecht im Dienste der Grafen von Honenberg, der Babenberger, König Ottokars II. von Böhmen und der Habsburger. Seine verschiedenen Zweige in Niederösterreich und Mähren, in Tirol und in der angestammten Heimat. Sigmaringen: Thorbecke,1989.

STRNAD, Alfred - Herzog Albrecht III. von Österreich (1365-1395). Ein Beitrag zur Geschichte Österreichs im späteren Mittelalter. Wien: University of Wien, 1961. PhD Thesis.

STUBENVOLL, Franz - “Aus dem Leben von Hanns Siebenhirter, erster Hochmeister des St. Georgs-Ritterordens (1420-1508)”. Studien zur Geschichte von Millstatt und Kärnten, Vorträge der Millstätter Symposien 1981 bis 1995. Klagenfurt: Habelt, 1997 (Archiv für vaterländische Geschichte und Topographie 78), pp. 495-510.

SWANSON, Robert N. - "Gens secundum cognationem et collectionem ab alia distincta? Thomas Polton, two Englands, and the challenge of medieval nationhood". in SIGNORI, Gabriela; STUDT, Birgit (eds.) - Das Konstanzer Konzil als europäisches Ereignis. Begegnungen, Medien und Rituale. Ostfildern: Th. Verlag, 2014 (Vorträge und Forschungen 79), pp. 57-87.

TOMASCHEK, Johann - "Kaiser Friedrich III. und der St. Georgs-Ritterorden - Fakten und Fiktionen“. Symposium zur Geschichte von Millstatt und Kärnten, ed. Franz Nikolasch (2011), pp. 1-22.

TOMASCHEK, Johann Adolf (ed.) - Die Rechte und Freiheiten der Stadt Wien. Wien: A. Höler, 1877 (Geschichts-Quellen der Stadt Wien, ed. Karl Weiß).

VANCSA, Max - Geschichte Nieder- und Oberösterreichs. Stuttgart-Gotha: Perthes, 1927 (Allgemeine Staatengeschichte $3 / 6 / 2$ ).

VISSIÈRE, Laurent - “L'île utopique. Rhodes ou l'union des nations chrétiennes". in Nation et nations au Moyen Âge. Actes du 44 congrès de la SHMESP Prague, 23 mai - 26 mai 2013. Paris: Publications de la Sorbonne, 2014 (Histoire ancienne et médiévale 130), pp. 311-325.

WAGNER, Wolfgang Eric - "Von der 'natio' zur Nation? Die 'nationes'-Konflikte in den Kollegien der mittelalterlichen Universitäten Prag und Wien im Vergleich”, Mitteilungen der Österreichischen Gesellschaft für Wissenschaftsgeschichte 20 (2000), pp. 141-162. 
WEISFLECKER-FRIEDHUBER, Inge - "Maximilian I. und der St. Georgs-Ritterorden“. Symposium zur Geschichte von Millstatt und Kärnten (1989), pp. 87-106.

WELTIN, Dagmar - Studien zur Geschichte der Johanniterkommende Mailberg. Wien: Wien University, 2007. MA Thesis. Available at http://othes.univie.ac.at/497/1/12-11-2007_0002309.pdf.

WIESFLECKER, Hermann - Kaiser Maximilian I. Das Reich, Österreich und Europa an der Wende zur Neuzeit. 5 vols. München: Oldenbourg, 1971-1986.

WIESSNER, Hermann - Die Schenken von Osterwitz. Geschichte eines durch fünf Jahrhundert führenden Kärntner Ministerialengeschlechtes. Klagenfurt: Heyn, 1977.

WOLF, Susanne - Die Doppelregierung Kaiser Friedrichs III. und König Maximilians (1486-1493). KölnWeimar-Wien: Böhlau, 2005 (Forschungen zur Kaiser- und Papstgeschichte des Mittelalters 25).

\section{APPENDIXES}

Eiwanowitz, Moravia, 1392 February 13 - Instrument made by Wenceslas, notary public by imperial authority, during the provincial chapter held by the Prior of Bohemia Fr. Marcold von Wrutzicz and his brethren in the great room (magna stuba) of the Hospitaller grange (curia) at Eiwanowitz.

Prague, Národní archiv, Maltézští rytî́ri - české velkopřevorství, n. 951.

Original on Parchment, $36.5 \mathrm{~cm} \times 51.3 \mathrm{~cm}$ plus $3.5 \mathrm{~cm}$ plica. Authenticated by the notary public and by 19 seals, affixed with strips of parchment; four seals are today missing. Available at http://monasterium.net/mom/CZ-NA/RM/951/charter.

In nomine Domini amen. Anno nativitatis eiusdem millesimo trecentesimo nonagesimo secundo, indictione quintadecima, die vero tredecima mensis Februarii, hora sexta vel quasi, pontificatus sanctissimi in Christo patris et domini nostri domini Bonifacii digna Dei providentia pape noni anno tertio, in mei notarii publici infrascripti testiumque presentia subscriptorum ad hoc specialiter vocatorum et rogatorum

[1] constitutus personaliter honorabilis vir frater Iohannes dictus Senk ${ }^{103}$ comendator in Firstenfeld ordinis sancti Iohannis hospitalis Ierosolimitani coram venerabili viro domino Marcoldo de Wruticz priore Boemie et cetera et aliis pluribus comendatoribus eiusdem ordinis ibidem in provinciali capitulo capitulariter congregatis petita et data sibi a dicto domino priore licencia surrexit et palio suo ad pedes dimisso et bureto deposito querimoniam seu planctam fecit de fratre Ottone dicto Lembucher comendatore in Morperga predicti ordinis Pathauiensis diocesis

dicens, quod ipse frater Otto in domo de Wyenna cistam suam, quam ibi servaverat, fregit et frangi mandavit et litteras ac privilegia ordinis recepit et deinde ipso Senkone in Wyenna propter necessitatem domus ac ordinis existente domum suam in Firstenfeld per potenciam intravit et sibi in vestibus, armis militaribus, in equis, in annonis et in vino sue persone et domus recepit ad valorem et summam noningentorum septuaginta quinque florenorum, in quibus est dampnificatus per eum, ut dicebat, dicens etiam, quod propter metum et timorem, qui posset in constantem virum cadere, ad dictam suam domum revenire non audebat et a vigilia purificationis sancte Marie anni proxime preteriti usque ad proximam dominicam ante diem sancti Martini de domo absens fuit. Dicebat eciam, quod pecora sunt ei per Ertolfum 
Kephensteiner dicti fratris Ottonis sororium et ex inductione eius recepta et famuli graviter volnerati. Subiunxit eciam, quod ipse frater Otto in Antiquo Foro fratrem ordinis ibidem ad ecclesiam confirmatum per potenciam expulit et secularem presbiterum ibidem instituit, qui presbiter petit omnia necessaria habere ab ordine.

[2] Quibus sic propositis frater Michael Sunram comendator in Wyenna similiter petita a domino priore licencia surrexit et querimoniam seu planctam fecit de fratre Ottone Lembucher supradicto

dicens, quod ipse frater Otto in die sancti Laurencii proxime preterito sibi fortalicium in Loch, quod est annexum et unitum domui sue in Wyenna, per potenciam recepit, et postea eum dominico die proximo post exaltacionem sancte Crucis preterito de domo sua Wyennensi similiter per potenciam expulit et eiecit et claves ac registra domus ei[us]dem recepit et voluit eum in Morpergam ducere captivum, si non evasisset, et fratrem Iohannem conventualem suum eciam expulit et eiecit et in Myelink dirrexit. Et dicebat, quod propter timorem et metum quinque septimanis de domo absens fuit et in rebus sue persone et domus in Loch in centum et septuaginta una libris et ex parte domus in Wyenna in quinquaginta duabus libris se dicebat dampnificatum esse. Dicens eciam, quod ipse frater Otto domum in Loch hodierna die ultra voluntatem sui prioris per potenciam possidet et detinet occupatam. Subiunxit eciam, quod ipse frater Otto de domo Wyennensi quedam privilegia tocius baiulie Austrie rapuit et evaginato gladio in famulum domus Wyenne irruit et voluit eum interficere. Et nescitur, quo talia privilegia fecit, et ex illa receptione privilegiorum ordo posset irrecuperabilia dampa incurrere, ut dicebat.

[3] Quibus sic deductis frater Oswaldus comendator ad sanctum Petrum in Carniola eciam petita a domino priore licencia surrexit et lamentum seu planctam fecit de fratre Ottone Lembucher memorato

dicens, quod ex inductione ipsius fratris Ottonis Lembucher dominica Iudica proxime preterita per ducem Austrie de domo sua predicta fuit eiectus et propter metum et timorem usque ad festum Omnium Sanctorum ad domum intrare non audebat. Et in vestibus, lectisterniis et aliis necessariis sue persone et domus dicebat se in centum et decem florenis dampnificatum esse propter eiectionem supradictam.

[4] Quibus eciam sic deductis frater Nicolaus dictus Hayko comendator in Myelink prefati ordinis de eodem fratre Ottone Lembucher plantam fecit

dicens, quod ipse frater Otto Lembucher suum notarium et suos cum sex censis[!] balistis in domum Mielink misit, qui ruptis cistis pecunias et alias res sue persone et domus receperunt per potenciam. Et dicebat, quod propter metum triginta septimanis absens fuit de domo. Et dicebat se propterea dampnificatum esse in centum et triginta florenis. Dicebat eciam, quod de mandato ipsius fratris Ottonis Lembucher fuit captivatus et in tali captivitate oportebat eum promittere et litteram sibi dare, quod super eum suo superiori de captivitate huiusmodi conqueri non deberet.

Quibus planctis omnibus factis taliter et deductis prefati fratres Iohannes Senk, Michael Sůnram, Oswaldus et Nicolaus Hayko comendatores dominum Marcoldum priorem suum supradictum cum instancia debita petiverunt, quod super dictis planctis aliquibus dominis comendatoribus ad pronuncciandum sentenciam seu esgardium comittere dignaretur secundum statuta ordinis. Quiquidem dominus prior sic rogatus hoc idem fratri Hersoni comendatori in Orlowicz locumtenenti per Morauiam, fratri Oczkoni 
comendatori in Wratislauia, Nicolao Stengel comendatori in Briga et fratri Nicolao comendatori in Cadana comisit. Qui assumptis sibi fratribus ad partem secesserunt et habito super dictis planctis consilio revenerunt. Et dominus Herso comendator in Orlowicz supradictus eorum nomine sic respondit, quod secundum consuetudinem ordinis, ex quo pars adversa absens est, nullum possunt ferre esgardium, sed a proxime futurum capitulum, postquam pars adversa presens fuerit, distulerunt.

Quibus omnibus taliter observatis, factis eciam et deductis, quia dominus prior in lingua Theutunica non bene extitit eruditus, fratri Iohanni comendatori in Sitauia comisit, quod eius nomine lamenta proponeret infrascripta. Quiquidem frater Iohannes de mandato dicti domini prioris et eius nomine proposuit cum querela et lamento, quod frater Otto dictus Lembucher comendator in Morperga ad hoc presens capitulum citatus et legitime evocatus et habens tempus sufficiens veniendi ad capitulum et ab initio capituli tribus diebus per dictum priorem et comendatores expectatus venire contumaciter non curavit. De quaquidem citacionis exsecucione dominus prior per testes ydoneos et publicum instrumentum fecit coram toto capitulo et me notario publico infrascripto bonam fidem. Quo facto predictus frater Iohannes prolocutor domini prioris prenotati super non comparicione et inobediencia et super rebellione cum castro Morperg et fortalicio Loch fratrum esgardium sibi fieri postulavit.

Fratres autem skardii fuerunt constituti et deputati, videlicet Herso de Orlowicz, Iohannes Oczko de Wratislauia, Nicolaus Stengel de Briga, Nicolaus de Cadana et Iohannes de Tincia domorum comendatores, qui assumptis quibusdam aliis sui ordinis fratribus ad partem secesserunt et habito ac maturato consilio, inspectis et intellectis sue religionis statutis reversi ad domini prioris et tocius capituli presenciam cum reverencia et humilitate steterunt. Quorum nomine dictus frater Iohannes Oczko esgardium maturatum protulit per omnia in hec verba dicens

"Venerabilis domine, fratres steterunt ad partem de mandato Dei et vestro super planctis per fratrem Iohannem prolocutorem vestro nomine factis et sunt in concordia, quod frater Otto dictus Lembucher preceptor domus in Morperg ex eo, quod inobediens et contumax repertus est non veniendo ad capitulum, penam ammocionis ab administracione incidit et debet ab ipsius domus in Morperg regimine ammoveri. Pro eo autem, quod se vobis, priori suo, cum castro Morperg et fortalicio Loch opponit rebellando, habitu privari et carceribus mancipari debet, non obstante eo, quod ad manus domini magni magistri est retentus."

De et super quibus omnibus supradictis actis, propositis atque gestis memoratus dominus prior me Wenceslaum notarium publicum infrascriptum meum invocando officium cum instancia debita requisivit, quod sibi unum vel plura conficerem publicum instrumentum seu publica instrumenta, quod et feci taliter requisitus.

Acta sunt hec in predicto provinciali capitulo per dominum priorem et preceptores prioratus Bohemia in Eywanowicz in curia ordinis in magna stuba celebrato anno, indictione, die, mense, hora, pontificatus et loco quibus supra, presentibus honorabilibus et religiosis fratribus Hinkone comendatore de Minori Boleslauia locumtenente prioris per Bohemiam, Nicolao de Strachonicz, Nicolao de Cadana, Mathia de Dub, Iohanne de Sitauia, Mathia de Glacz domorum preceptoribus in Bohemia, fratre Iohanne Oczkone comendatore in Wratislauia locumtenente in Polonia, Petro de Lemberk, Iohanne de Golthperg, Nicolao de Reychenbach, Iohanne de Strigouia, Iohanne de Tincia, Iohanne de Olsna, Nicolao de Briga, Henrico de Lichtnawe, 
Petro de Lubczicz, Nicolao de Opauia, Paulo de Kosla, Paulo de Mokaw domorum preceptorius in Polonia, fratre Hersone de Orlowicz locumtenente prioris per Morauiam, Vilhelmo de Cremsier, Thoma de Brunna, Sdenkone de Cunicz, Philippo de Pirnicz domorum preceptoribus in Morauia, fratre Iohanne Senkone comendatore de Firstenfeld locumtenente prioris in Austria, Michaele dicto Sundram de Wyenna, Oswaldo de sancto Petro de Carniola, Nicolao de Hayko de Myelink domorum preceptoribus in Austria, Vlrico priore ecclesie in Morperga, Michaele dicto Nicol plebano in Erpurg, Iohanne Reychensteiner et fratre Petro Thaubencraff conventualibus in Morperg testibus cum prefato domino priore capitulum celebrantibus supradictum.

[signetum notarii]. Et ego Wenceslaus natus Milaczkonis de Rokyczana Pragensis diocesis, publicus auctoritate imperiali notarius, dictarum planctarum et lamentorum propositionibus et deductionibus omnibusque aliis et singulis suprascriptis una cum prenominatis testibus et domorum preceptoribus presens interfui eaque omnia et singula sic fieri vidi et audivi manuque propria conscripsi et in hanc formam publicam redegi signoque et nomine meis solitis et consuetis una cum appensione sigillorum quorundam seniorum preceptorum predictorum hoc presens instrumentum de eorum certa sciencia consignavi requisitus et rogatus in fidem et testimonium ac maioris roboris firmitatem omnium premissorum.

Note on the back, $15^{\text {th }}$ century: Instrumentum publicum super planctam contra preceptorem in Mailperg factam coram domino Marcoldo priore Boemie, in qua plerique preceptores notantur, quocumque[?] ${ }^{104}$ preceptorie iamiam expirar

\section{Contents in English}

Eiwanowitz (in der Hanna) ${ }^{105} 1392$ February 13: Wenceslas, son of Milaczko, from Rokycany ${ }^{106}$ in the diocese of Prague, notary public by imperial authority, issues an instrument during the provincial chapter held by the Prior of Bohemia Fr. Marcold von Wrutzicz and his brethren in the great room (magna stuba) of the Hospitaller grange (curia) at Eiwanowitz and relates the following events.

With licence of the prior and the chapter four brethren complained against Fr. Otto Lembucher, Commander of Mailberg in the diocese of Passau:

(1) Fr. Johann Schenk, Commander of Fürstenfeld ${ }^{107}$, was robbed of a chest he had in the commandery in Vienna with letters and privileges of the Order. At Fürstenfeld he was robbed of clothing, arms, horses, corn and wine. His losses amounted to the worth of 975 florins. For fear he had to be absent from Fürstenfeld from 2 February 1391 to 5 November 1391. Fr. Otto's brother-in-law Ertolf Kephensteiner took away his sheep and wounded his servants. At Altenmarkt ${ }^{108} \mathrm{Fr}$. Otto expelled the Hospitaller brother who held the church and replaced him by a secular priest whom the Order was forced to pay.

(2) Fr. Michael Sindram, Commander in Vienna, complained that on 10 August 1391 Fr. Otto expelled him from the fortified place at $\mathrm{Laa}^{109}$ that belonged to the house in Vienna, and on 17 September $1391 \mathrm{Fr}$. Otto expelled him from the house in Vienna itself, took the keys and the registers of that house and would have taken him as a prisoner to Mailberg if he had not escaped. Fr. Johann, a conventual brother at Vienna, was also expelled and directed towards Melling ${ }^{110}$. Out of fear, Fr. Michael had to be absent from Vienna for five weeks. Moreover, Fr. Michael lost at Laa valuables worth 
171 pounds and at Vienna valuables worth 50 pounds. Fr. Otto still occupied Laa. With his drawn sword, Fr. Otto had forced a servant of the house of Vienna to hand over the privileges of the bailiwick of Austria, and this may cause great damage to the Order.

(3) Fr. Oswald, Commander of St. Peter in Carniola ${ }^{111}$, complained that Fr. Otto and the Duke of Austria (Albert III) had expelled him from his house on 12 March 1391 and that he had not dared to return until 1 November 1391. The cloths, beds and other utensils of his person and his house he had lost were worth 110 florins.

(4) Fr. Nicolas Hayko, Commander of Melling, complained that Fr. Otto, his notary, his retainers and his six leased crossbowmen robbed chests with monies and other belongings of his person and of his house. Out of fear, he had to be absent from his house for 30 weeks. His damage amounted to 130 florins. Fr. Otto imprisoned him and forced to promise under oath not to complain about his imprisonment.

These four Hospitallers asked the prior to permit an esgard. For this purpose, the prior appointed the commanders Fr. Herso at Orlowitz ${ }^{112}$, lieutenant for Moravia, Fr. Oczko in Breslau $^{113}$, Fr. Nicolas Stengel at Brieg ${ }^{114}$ and Fr. Nicolas at Kaaden ${ }^{115}$. These four departed, held deliberations among themselves and returned. Then Fr. Herso pronounced the following esgard: As the opposing party was not present, the Order's consuetudo did not allow an esgard; the opposing party should be summoned to the next provincial chapter.

As the prior could not speak German well, he commissioned Fr. Johann, Commander at $\mathrm{Zittau}^{116}$, as his prolocutor to put forward the following complaint against Fr. Otto Lembucher. As proved by the instrument of a notary public that was read to the chapter, Lembucher had been legitimately summoned to the present chapter and the chapter had waited for him for three days, but he did not come. So the prior asked for an esgard against Lembucher. For his disobedience and rebellion, Lembucher should be deprived of the castle of Mailberg and the fortified place at Laa.

Four brethren were commissioned to find the esgard, the commanders Fr. Herso at Orlowitz, Fr. Johann Oczko in Breslau, Fr. Nicolas Stengel at Brieg, Fr. Nicolas at Kaaden and Fr. Johann at Tinz ${ }^{117}$. They departed, held deliberations among themselves and returned. Then Fr. Johann Oczko pronounced the following esgard: For his disobedience and contumacy, Fr. Otto Lembucher would lose the castle of Mailberg and the fortified place of Laa and would be deprived of his habit and incarcerated, notwithstanding that the Master from Rhodes had retained him under his special jurisdiction (i.e. that he was retentus ad manus by the magnus magister) ${ }^{118}$.

The 34 witnesses were (1) the prior's lieutenant for Bohemia Fr. Hinko, Commander of Jungbunzlau ${ }^{119}$, and the six commanders Fr. Nicolas at Strakonitz ${ }^{120}$, Fr. Nicolas at Kaaden, Fr. Matthias at Dub ${ }^{121}$, Fr. Johann at Zittau and Fr. Matthias at Glatz ${ }^{122}$, (2) the prior's lieutenant for Silesia (Polonia) Fr. Johann Oczko, Commander of Breslau, and the twelve commanders Fr. Petrus at Löwenberg ${ }^{123}$, Fr. Johann at Goldberg ${ }^{124}$, Fr. Nicolas at Reichenbach $^{125}$, Fr. Johann at Striegau ${ }^{126}$, Fr. Johann at Tinz, Fr. Johann at Oels ${ }^{127}$, Fr. Nicolas at Brieg, Fr. Henry at Lichtenau ${ }^{128}$, Fr. Peter at Leobschütz ${ }^{129}$, Fr. Nicolas at Troppau $^{130}$, Fr. Paul at Kosel ${ }^{131}$ and Fr. Paul at Makau ${ }^{132}$, (3) the prior's lieutenant for Moravia Fr. Herso at Orlowitz, and the four commanders Fr. William at Kremsier ${ }^{133}$, Fr. Thomas at Brünn ${ }^{134}$, Fr. Zdeněk at Kaunitz ${ }^{135}$ and Fr. Philip at Pirnitz ${ }^{136}$, (4) the prior's lieutenant for Austria Fr. Johann Schenk, Commander at Fürstenfeld, and the four commanders Fr. Michael Sindram at Vienna, Fr. Oswald at St. Peter in Carniola 
(Krain), Fr. Nicolas of Hayko at Melling, (5) and four Hospitallers from Mailberg, Fr. Ulrich, Prior ${ }^{137}$ of the church at Mailberg, Fr. Michael Nicol, Parson at Erdburg ${ }^{138}$, Fr. Johann Reichensteiner and Fr. Peter Taubencraff, two conventual brethren at Mailberg.

\section{NOTES}

1. HERNANDO SÁNCHEZ, Carlos José (ed.) - Roma y España un crisol de la cultura europea en la Edad Moderna. Actas del Congreso Internacional celebrado en la Real Academia de España en Roma del 8 al 12 de mayo de 2007. Madrid: Sociedad Estatal para la Acción Cultural Exterior, 2007; PETTI BALBI, Giovanna (ed.) - Comunità forestiere e "nationes" nell'Europa dei secoli XIII-XVI. Napoli: Liguori Ed., 2001 (Europa mediterranea. Quaderni 19); BUES, Almut; REXHEUSER, Rex (eds.) - Mittelalterliche nationes, neuzeitliche Nationen. Probleme der Nationenbildung in Europa. Wiesbaden: Harrassowitz, 1995 (Deutsches Historisches Institut, Warschau, Quellen und Studien 2); BEUMANN, Helmut; SCHRÖDER, Werner (eds.) - Nationes. Historische und philologische Untersuchungen zur Entstehung der europäischen Nationen im Mittelalter, 9 vols. Sigmaringen: Th. Verlag, 1978-1991.

2. See for example PETTI BALBI, Giovanna - Mercanti e nationes nelle Fiandre: $i$ genovesi in età bassomedievale. Pisa: ETS, 1996 (Piccola biblioteca Gisem 7).

3. KIBRE, Pearl - The Nations in the Medieval Universities. Cambridge/Mass.: Mediaeval Academy of America, 1948 (The Mediaeval Academy of America, 49); WAGNER, Wolfgang Eric - "Von der 'natio' zur Nation? Die 'nationes'-Konflikte in den Kollegien der mittelalterlichen Universitäten Prag und Wien im Vergleich". Mitteilungen der Österreichischen Gesellschaft für Wissenschaftsgeschichte 20 (2000), pp. 141-162; PINI, Antonio Ivan - "Le 'nationes' studentesche nel modello universitario bolognese del Medioevo”. in BRIZZI, Gian Paolo; ROMANO, Andrea (eds.) Studenti e dottori nelle università italiane (origine-XX secolo). Atti del Convegno di studi (Bologna, 25-27 novembre 1999). Bologna: Clueb, 2000, pp. 21-29.

4. At the University of Vienna for example the Hungarian nation included Czech- and German-speaking men from Bohemia, Moravia and Silesia: MÜHLBERGER, Kurt “Relikte aus dem Mittelalter: Die 'Akademischen Nationen' im Rahmen der neuzeitlichen Universitätsgeschichte. Mit einem Exkurs zur Natio Hungarica Universitatis Vindobonensis". in LENGYEl, Zsolt K. (ed.) - Österreichisch-ungarische Beziehungen auf dem Gebiet des Hochschulwesens / Osztrák-magyar felsőoktatási kapcsolatok. Székesfehérvár - Budapest: Kodolányi János Főiskola - Eötvös Loránd Tudományegyetem Könyvtára, 2010, pp. 11-32.

5. FINKE, Heinrich - "Die Nation in den spätmittelalterlichen Konzilien”. Historisches Jahrbuch 57 (1937), pp. 323-338, reprint in BÄUMER, Remigius (ed.) - Die Entwicklung des Konziliarismus. Werden und Nachwirken der konziliaren Idee. Darmstadt: Wissenschaftliche Buchgesellschaft, 1976 (Wege der Forschung 279), pp. 347-368; BRANDMÜLLER, Walter - Das Konzil von Pavia-Siena 1423-1424. Paderborn: Ferdinand Schoningh, 2002 (Konziliengeschichte A 18), pp. 233-42; HELMRATH, Johannes - Das Basler Konzil 1431-1449. Forschungsstand und Probleme. Köln: Böhlau, 1987 (Kölner Historische Abhandlungen 32), pp. 47-51. On problems concerning nationes see now SWANSON, Robert N. - "Gens secundum cognationem et collectionem ab alia distincta? Thomas Polton, two Englands, and the challenge of medieval nationhood". in SIGNORI, Gabriela; STUDT, Birgit (eds.) Das Konstanzer Konzil als europäisches Ereignis. Begegnungen, Medien und Rituale. Ostfildern: Verlag, 2014 (Vorträge und Forschungen 79), pp. 57-87.

6. FROMME, Bernhard - "Die Wahl des Papstes Martin V". Römische Quartalschrift für christliche Altertumskunde und Kirchengeschichte 10 (1896), pp. 133-162. 
7. DENDORFER, Jürgen - "Wer wird Kardinal? Kardinalskarrieren und die Zusammensetzung des Kollegs (1417-1471)”. in DENDORFER, Jürgen; LÜTZELSCHWAB, Ralf - Geschichte des Kardinalats im Mittelalter. Stuttgart: Anton Hiersemann, 2011 (Päpste und Papsttum 39), pp. 361-372, here pp. 362-364, with further references.

8. SARNOWSKY, Jürgen - Macht und Herrschaft im Johanniterorden des 15. Jahrhunderts. Verfassung und Verwaltung der Johanniter auf Rhodos (1421-1522). Münster/Westfalen: Verlag, 2001(Vita regularis 14), pp. 147-169; VISSIÈRE, Laurent - "L'île utopique. Rhodes ou l'union des nations chrétiennes". in Nation et nations au Moyen Âge. Actes du 44e congrès de la SHMESP Prague, 23 mai - 26 mai 2013. Paris: Publications de la Sorbonne, 2014 (Histoire ancienne et médiévale 130), pp. 311-325.

9. Since 1626 according to DAUBER, Robert L. - Die Johanniter-Malteser Orden in Österreich und Mitteleuropa. 850 Jahre gemeinsamer Geschichte, vol. 3: Neue Zeit (1618 bis 1798). Wien: [private printing], 1998, pp. 668, 777, 848.

10. An invaluable treasure trove for the Hospitallers in former Habsburg lands is DAUBER, Robert L. - Die Johanniter-Malteser ..., vol. 2: Spätmittelalter und frühe Neuzeit (1291 bis 1618). Dauber's publications are very useful, but his references should always be carefully checked.

11. Such lieutenancies, baiulie, bailiwicks or in German Balleien may have been a peculiarity of the Empire north of the Alps: BORCHARDT. Karl (ed.) - Documents Concerning Central Europe from the Hospital's Rhodian Archives, 1314-1428. Abingdon-New York: Routledge, 2020 (The Military Religious Orders: History, Sources and Memory), pp. xix-xxi. They included Flanders under the Priory of Francia and Lorraine under the Priory of Champagne.

12. LECHNER, Karl - “Die Kommende Mailberg”. in WIENAND, Adam - Der Johanniter-Orden. Köln: Wienand-Verlag, 1970, pp. 413-425; FÜRNKRANZ, Rudolf (ed.) - Mailberg. Ein Abriß der Ortsgeschichte. Festschrift anläßlich der Verleihung des Marktwappens durch die Landesregierung am 23. Oktober 1999. Mailberg, 1999; on the history to the thirteenth century, WELTIN, Dagmar - Studien zur Geschichte der Johanniterkommende Mailberg. Wien: Wien University, 2007. PhD Thesis, available at http://othes.univie.ac.at/497/1/12-11-2007_0002309.pdf); on charters in Prague, HLAVÁčEK, Ivan; HLEDÍKOVÁ, Zdeňka 8eds.) - Nichtbohemikale mittelalterliche Originalurkunden in den böhmischen Ländern. Köln - Wien: Böhlau-Verlag, 1977 (Archiv und Wissenschaft 1), pp. 87-88.

13. DEMEL, Bernhard - "Zur Geschichte der Johanniter und des Deutschen Ordens in Kärnten". in NIKOLASCH, Franz (ed.) - Studien zur Geschichte von Millstatt und Kärnten, Vorträge der Millstätter Symposien 1981 bis 1995. Klagenfurt: Habelt, 1997 (Archiv für vaterländische Geschichte und Topographie 78), pp. 787-826.

14. Fr. Johann probably belonged to the Schenk (pincerna) von Osterwitz, today Hochosterwitz in Carinthia, who held the hereditary office of Erbschenk in Carinthia and were one of the leading families also in Styria and Carniola. See also Fr. Engelhard Schenk, Commander of St. Peter in Carniola in 1457: DAUBER, Robert L. - Die Johanniter-Malteser ..., vol. 2, p. 590. Neither of the two Hospitallers is mentioned by WIESSNER, Hermann - Die Schenken von Osterwitz. Geschichte eines durch fünf Jahrhundert führenden Kärntner Ministerialengeschlechtes. Klagenfurt: Heyn, 1977.

15. Czech: z Vrutic.

16. JAN, Libor - "Ivanovice na Hané, Orlovice a johanitský řád (Př́spěvek k poznání struktury a ekonomiky rytíŕských duchovních řádů do konce 15. století)”. Časopis Matice Moravské 111 (1992), pp. 199-226, here pp. 211-213; JAN, Libor - "Die Entwicklung des böhmischen Priorats der Johanniter". in BORCHARDT, Karl and JAN, Libor (eds.) - Die Geistlichen Ritterorden in Mitteleuropa: Mittelalter. Brno: Matice moravská, 2011 (Země e kultura ve střední Evropě 20), pp. 79-98, here pp. 95-6; LUTTRELL, Anthony - “The Hospitaller Province of Alamania to 1428”, in NOWAK, Zenon Hubert (ed.) - Ritterorden und Region - politische, soziale und wirtschaftliche Verbindungen im Mittelalter, Toruń: Uniw. Mikołaja Kopernika, 1995 (Ordines Militares. Colloquia Torunensia Historica 8), pp. 21-41, here pp. 34-5 with note 91, reprint in The Hospitaller State on Rhodes and its 
western Provinces, 1306-1462. Aldershot: Ashgate, 1999 (Variorum Collected Studies Series 655), n. XII.

17. For examples from the Priory of Alamania see BORCHARDT, Karl - "Hospitaller chapters in the medieval priory of Alamania". in MORTON, Nicholas (ed.) - Piety, Pugnacity and Property. Vol. 7. The Military Orders. Abingdon-New York: Routledge, 2020, pp. 195-207.

18. Albert III's court was famous for literary patronage: SCHNEIDER, Christian - "Höfische Lebensform und gesellschaftliche Identität. Literarische Texte um Herzog Albrecht III. von Österreich". in DARTMANN, Christoph; MEYER, Carla - Identität und Krise? Zur Deutung vormoderner Selbst-, Welt- und Fremderfahrungen. Münster/Westfalen: Rhema, 2007, pp. 85-95; MEYER, Carla - "Eliten des Hofes - Eliten der Stadt. Ständische Verhaltenskonzepte und gesellschaftliche Identitätsbildung im Reflex der Literatur um Herzog Albrecht III. von Habsburg (1365-1395)". in PARAVICINI, Werner; WETTLAUFER, Jörg (eds.) - Der Hof und die Stadt. Konfrontation, Koexistenz und Integration in Spätmittelalter und früher Neuzeit. 9. Symposium der Residenzen-Kommission, Halle an der Saale, 25.-28. September 2004. Ostfildern: Th. Verlag, 2006, pp. 449-470.

19. This tax allegedly yielded 100,000 pounds: "Wiener Annalen von 1348-1404". in SEEMÜLLER, Joseph (ed) - Österreichische Chronik von den 95 Herrschaften. Hannover: Hahn 1909, pp. 231-242, here 235. On the background, STRNAD, Alfred - Herzog Albrecht III. von Österreich (1365-1395). Ein Beitrag zur Geschichte Österreichs im späteren Mittelalter. Wien: University of Wien, 1961. PhD Theis, p. 230; GUTKAS, Karl - Geschichte des Landes Niederösterreichs, 4th ed. St. Pölten - Wien: NÖ Pressehaus, 1984), pp. 103-104.

20. Vienna, 1389 December 27: TOMASCHEK, Johann Adolf (ed.) - Die Rechte und Freiheiten der Stadt Wien. Wien: A. Höler, 1877 (Geschichts-Quellen der Stadt Wien, ed. Karl Weiß), p. 201 n. 100. Renewed Vienna, 1391 December 13: TOMASCHEK, Johann Adolf (ed.) - Die Rechte und Freiheiten ..., pp. 202-203, n. 101.

21. 1391 November 23: KURZ, Franz - Österreich unter Herzog Albrecht III., 2 vols. Linz: Haslinger, 1827, here vol. 2, pp.149-52, 282-284 n. 78. See VANCSA, Max - Geschichte Nieder- und Oberösterreichs, Stuttgart - Gotha: Perthes, 1927 (Allgemeine Staatengeschichte 3/6/2), p. 180.

22. LACKNER, Christian - Hof und Herrschaft: Rat, Kanzlei und Regierung der österreichischen Herzoge (1365-1406). Wien-München: Oldenbourg, 2002 (Mitteilungen des Instituts für Österreichische Geschichtsforschung, Ergänzungsband 41), pp. 299-309. On the family see MITIS, Oskar von - "Die schwäbischen Herren von Wehingen in Österreich - ein Beispiel für Familienwanderung im Mittelalter". Jahrbuch für Landeskunde von Niederösterreich. Ser. NF, 23 (1930), pp. 76-92, here p. 82 note 2; STIERLE, Leopold - Die Herren von Wehingen. Ein schwäbisches Rittergeschlecht im Dienste der Grafen von Honenberg, der Babenberger, König Ottokars II. von Böhmen und der Habsburger. Seine verschiedenen Zweige in Niederösterreich und Mähren, in Tirol und in der angestammten Heimat. Sigmaringen: Thorbecke, 1989, pp. 26-28.

23. He was mentioned Vienna, 1371 November 5: Regesta Habsburgica. Regesten der Grafen von Habsburg und derHerzoge von Österreich aus dem Hause Habsburg, V. Abteilung: Die Regesten der Herzoge von Österreich 1365-1395, 2. Teilband (1371-1375). Ed. Christian Lackner in collaboration with Claudia Feller and Stefan Seitschek. Wien-München: Böhlau, 2010, p. 68, n. 826.

24. Undated letter of supplication by which Duke Albert III asked the Prior of Bohemia [Duke Ziemovit of Teschen] to appoint Fr. Hugo von Wehingen as successor of the now ill and probably soon dead commander of Mailberg: Regesta Habsburgica ..., p. 159 n. 1059, from a formulary Gießen, Universitätsbibliothek 632 fol. 40r-v. The date is supposed to be between 1373 and 1379 . The text mentions Fr. Hugo's carnal brother Reinhard von Wehingen, Kammermeister and later Hofmeister of Duke Leopold III.

25. SENCKENBERG, Heinrich Christian (ed.) - Selecta iuris et historiarum tum anecdota tum iam edita, sed rariora, IV/2. Frankfurt am Main, 1738, pp. 280-81, n. 80; PETERS, Henriette - Ein Formelbuch aus der Kanzlei Albrechts $V$., unpublished paper from the Institut für Österreichische 
Geschichtsforschung. Wien, 1956, pp. 9-11 n. 5. - On Caracciolo, DELAVILLE LE ROULX, Joseph Les Hospitaliers à Rhodes jusqu'à la mort de Philibert de Naillac (1310-1421). Paris: Leroux, 1913, pp. 248-264; HUNYADI, Zsolt - The Western Schism and Hungary: From Louis I to Sigismund of Luxembourg. Chronica 13 (2017), pp. 45-53.

26. BORCHARDT. Karl (ed.) - Documents Concerning Central Europe ..., p. 129, n. 146.

27. BORCHARDT. Karl (ed.) - Documents Concerning Central Europe ..., p. 135, n. 153.

28. STIERLE, Leopold - Die Herren von Wehingen ..., pp. 27-28 with notes 23-31; DAUBER, Robert L. Die Johanniter-Malteser ..., vol. 2, pp. 583, 586-87.

29. LACKNER, Christian - Ein Rechnungsbuch Herzog Albrechts III. von Österreich. Edition und Textanalyse. Wien: Selbstverlag des NÖ Instituts für Landeskunde, 1996 (Studien und Forschungen aus dem Niederösterreichischen Institut für Landeskunde 23), p. 22 with note 30; PRIBRAM, Albert Francis - Materialien zur Geschichte der Preise und Löhne in Österreich 1. Wien: Carl Ueberreuter, 1938, p. 20; SPUFFORD, Peter - Handbook of Medieval Exchange. London: Royal Historical Society, 1986 (Royal Historical Society, Guides and Handbooks 13), pp. 266, 271-272. One pound was 240 pennies. In the fourteenth century the florin started with 120 pennies and in sixteenth it ended up with 240 pennies. Ratios per florin 1390: 126 d, 1391: 132 d, 1391-2: 132,5 d, 1392: 138d, 1393: 144 d, 1394-1401: 150d.

30. MITÁČEK, Jiří - "Die böhmische Provinz des Johanniterordens und die Luxemburger 1310-1437". in BORCHARDT, Karl; JAN, Libor - Die geistlichen Ritterorden in Mitteleuropa, Mittelalter. Brno: Matice moravská, 2011 (Země e kultura ve střední Evropě 20), pp. 99-113, here p. 111.

31. 1392 January 13 and 14: KURZ, Franz - Österreich unter Herzog ..., vol. 2, pp. 152-155, 282-87 n. 79,288 n. 80.

32. 1390 June 2: KURZ, Franz - Österreich unter Herzog ..., vol. 2, pp. 276-79 n. 75.

33. 1391 September 14: LÜNIG, Johann Christian (ed.) - Codex Germaniae diplomaticus. Frankfurt/ Main, 1732, vol. 1, col. 1403-1406 n. 330.

34. KRAUS, Thomas R. - "Eine unbekannte Quelle zur ersten Gefangenschaft König Wenzels im Jahre 1394". Deutsches Archiv zur Erforschung des Mittelalters 43 (1987), pp. 135-195; ŠTĚPÁN, Václav - Moravsky markrabě Jošt (1354-1411). Brno: Matice moravská, 2002 (Kniznice Matice Moravské 10), pp. 351-375.

35. DAUBER, Robert L. - Die Johanniter-Malteser ..., vol. 2, pp. 586-588.

36. DAUBER, Robert L. - Die Johanniter-Malteser ..., vol. 2, p. 583 and p. 586.

37. Vienna 1406 December 6: SCHWIND, Ernst Freiherr; DOPSCH, Alphons (eds.) - Ausgewählte Urkunden zur Verfassungs-Geschichte der deutsch-österreichischen Erblande im Mittelalter. Innsbruck: Wagner, 1895, pp. 300-302 n. 159. The charter calls him Ott maister zu Maurperg; it is not said that he was a Hospitaller. For the background NIEDERSTÄTTER, Alois - Die Herrschaft Österreich. Fürst und Land im Spätmittelalter. Wien: Ueberreuter, 2001 (Österreichische Geschichte 1278-1411, ed. Herwig Wolfram), pp. 286-287.

38. The reference to Fr. Hans (Johannes) in 1403 is a mistake of DAUBER, Robert L. - Die Johanniter-Malteser ..., vol. 2, pp. 583, 587.

39. DAUBER, Robert L. - Die Johanniter-Malteser ..., vol. 2, p. 583.

40. See below note . Priest-brother and Commander of St. Peter in Carniola 1493 and 1446: DAUBER, Robert L. - Die Johanniter-Malteser ..., vol. 2, p. 590. It deserves further investigation whether the documents from 1403 to 1468 really refer to one and the same person.

41. 1473 October 13: Repertorium Germanicum X. Verzeichnis der in den Registern und Kameralakten Sixtus' IV. vorkommenden Personen, Kirchen und Orte des Deutschen Reiches, seiner Diözesen und Territorien 1471-1484. Berlin - Boston: De Gruyter, 2018, n. 6754.

42. St. Peter, 1494 February 25: Prague, Národní archiv, Maltézští rytíríi - české velkopřevorství n. 3097. References to the charters in Prague [Online]. [accessed at 9 June 2020]. Available at https://www.monasterium.net/mom/CZ-NA/RM/fond. 
43. Fr. Martin Kefer[!], 1433 January 11: Prague, Národní archiv, Maltézští rytíři - české velkopřevorství, n. 2093; 1438 June 7: Prague, Národní archiv, Maltézští rytíríi - české velkopřevorství, n. 2097; 1438 September 14: Prague, Národní archiv, Maltéžstí rytíríi - české velkopřevorství, n. 1653.

44. GUTKAS, Karl - "Der Mailberger Bund von 1451. Studien zum Verhältnis von Landesfürst und Ständen um die Mitte des 15. Jahrhunderts". Mitteilungen des Instituts für Österreichische Geschichtsforschung 74 (1966), pp. 51-94, 347-392, here pp. 357, pp. 389-392, n. 4. Fr. Wilhelm sealed as n. 14, followed by two relatives, n. 15 Heinrich Dachsner and n. 16 Nikolaus Dachsner (zu Mörtersdorf).

45. LANGMAIER, Konstantin Moritz A. - Erzherzog Albrecht VI. von Österreich (1418-1463). Ein Fürst im Spannungsfeld von Dynastie, Regionen und Reich. Köln: Böhlau, 2015 (Forschungen zur Kaiser- und Papstgeschichte des Mittelalters 38), pp. 491-647; CSENDES, Peter; OPLL, Ferdinand (eds.) - Wien. Geschichte einer Stadt. Vol. 1: Von den Anfüngen bis zur ersten Wiener Türkenbelagerung (1529). Wien: Böhlau, 2001, pp. 157-164.

46. See his charters for Stephan von Eitzing, 1463 February 25: Archiv für österreichische Geschichte 1 (1848), pp. 34-35 ns. 166, 1463 February 26: Archiv für österreichische Geschichte 1 (1848), p. 35 n. 168; MOCHTY-WELTIN, Christina - "Inventarium der Eitzingerischen brieff in der grossen truhen liegendt". NÖLA Mitteilungen aus dem Niederösterreichischen Landesarchiv 15 (2012), pp. 212-263, 17 (2016), pp. 178-369. - Fr. Achaz Bohunko was also mentioned on 26 March 1466: Geschichte des Benedictiner-Stiftes Melk in Niederösterreich, seiner Besitzungen und Umgebungen 2/2. Wien: Beck, 1869 , p. 666. He acquired possessions from the brothers Oswald and Stephen von Eitzing, Wiener Neustadt, 1472 September 23: Prague, Národní archiv, Maltézští rytírí - české velkopřevorství n. 1465; Regesta Imperii XIII, 26, n. 663. Similarly he acquired tithes from a certain Stephan Bierbaumer, Graz, 1478 July 23: Regesta Imperii XIII, 26 n. 716. References to the Regesta Imperii [Online]. [accessed at 25 November 2020]. Available at http://www.regesta-imperii.de/regesten/ suche.html.

47. HEINIG, Paul-Joachim - Kaiser Friedrich III. (1440-1493). Hof, Regierung, Politik. 3 vols., Köln Weimar - Wien: Böhlau, 1997 (Forschungen zur Kaiser- und Papstgeschichte des Mittelalters 17), vol. 1, p. 45 with note 39.

48. Today Velika-Nedelja, east of Pettau, Slovene: Ptuj, in Slovenia.

49. Wiener Neustadt, 1455 May 2: Regesta Imperii XIII, 24 n. 201; Count Ulrich, 1455 May 10.

50. Slovene: Ljubljana.

51. Wiener Neustadt, 1458 September 16: Regesta Imperii XIII, 24 ns. 206-207, mentioning Bohunko's letter to the Highmaster, Laibach, 1457 June 3.

52. 1459 September 23: Regesta chronologico-diplomatica Friderici III Romanorum Imperatoris (Regis IV). Ed. Joseph Chmel. Wien, 1840, p. 374, n. 3750.

53. BACHMANN, Adolf - Deutsche Reichsgeschichte im Zeitalter Friedrichs III. und Max I. Vol. 1, Leipzig, 1884, p. 478; FILIP, Václav; BORCHARDT, Karl -Schlesien, Georg von Podiebrad und die römische Kurie. Würzburg: Verein für Geschichte Schlesiens, 2005 (Wissenschaftliche Schriften des Vereins für Geschichte Schlesiens 6), pp. 81-106.

54. Czech: Jošt z Rožmberka. He had been Prior of Bohemia at Strakonitz since 1452. In 1456 he became Bishop of Breslau. In this context he had to resign the office of Provost of the cathedral in Prague: FILIP, Václav; BORCHARDT, Karl - Schlesien, Georg von Podiebrad ..., pp. 65-66. Jodok died on 11 November 1467. For the Priory of Bohemia an administrator was appointed, Fr. Heinrich von Platz an der Naser, Stráž nad Nežárkou: DAUBER, Robert L. - Die Johanniter-Malteser ..., vol. 2, p. 580 .

55. 1468 April 1 from 1460 January 10: V 528 fol. 233r-234r. Repertorium Germanicum IX: Verzeichnis der in den Registern und Kameralakten Pauls II. vorkommenden Personen, Kirchen und Orte des Deutschen Reiches, seiner Diözesen und Territorien, 1464-1471. Tübingen: Max Niemeyer Verlag, 2000, n. 4539; 
Materialien zur österreichischen Geschichte. Aus Archiven und Bibliotheken. Ed. Joseph Chmel, vol. 2. Wien, 1840, pp. 297-98, n. 234.

56. MITÁČEK, Jiří. - "Strakonice ve struktuře Cěské provincie řadu johanitů za vlády Lucemburků”. Jihočeský Sborník Historický 75 (2006), pp. 40-61.

57. 1468 April 1 from 1460 January 10: V 528 177r-178r; Repertorium Germanicum IX ..., n. 4539; Materialien zur österreichischen ..., pp. 296-297, n. 233.

58. 1468 July 22: S 628 fol. 1v-2r; Repertorium Germanicum IX ..., n. 4539.

59. Graz, 1470 November 14: Regesta chronologico-diplomatica ..., p. 595 n. 6134.

60. WEISFLECKER-FRIEDHUBER, Inge - "Maximilian I. und der St. Georgs-Ritterorden". Symposium zur Geschichte von Millstatt und Kärnten (1989), pp. 87-106, here p. 87: ... entsprach offenbar nicht mehr der Zeit". St. George of Millstatt was supposed to have fully professed members with the three solemn vows of chastity, poverty and obedience, contrary to the new monarchical orders of chivalry that began to found in the later Middle Ages. But see BOULTON, D'Arcy Jonathan Dacre - The Knights of the Crown. The Monarchical Orders of Knighthood in Later Medieval Europe 1325-1520. Woodbridge: Boydell, 1987, p. 399 with note 7, p. 483.

61. STUBENVOLL, Franz - "Aus dem Leben von Hanns Siebenhirter, erster Hochmeister des St. Georgs-Ritterordens (1420-1508)". in NIKOLASCH, Franz (ed.) - Studien zur Geschichte von Millstatt und Kärnten, Vorträge der Millstätter Symposien 1981 bis 1995. Klagenfurt: Habelt, 1997, pp. 495-510.

62. TOMASCHEK, Johann - "Kaiser Friedrich III. und der St. Georgs-Ritterorden - Fakten und Fiktionen“. Symposium zur Geschichte von Millstatt und Kärnten, ed. Franz Nikolasch (2011), pp. 1-22, here pp. 9-14. And TOMASCHEK, Johann - "Kaiser Friedrich III (...)" ..., pp. 4-9 against the myth that Frederick III vowed the foundation while he was besieged in Vienna in 1462.

63. “... ad laudem et gloriam omnipotentis Dei ac gloriose virginis Marie, pro exaltacione quoque catholice fidei, anime sue salute ac domus Austrie, a qua originem traxit, commemoratione et decore ...": Lateran, 1469 January 1: Monumenta Ducatus Carinthiae. Ed. Hermann Wiessner, vol. 11: Die Kärntner Geschichtsquellen 1414-1500. Klagenfurt: Kartner Druckere, 1972, pp. 160-164, n. 406.

64. Italian: Gorizia, Slovene: Gorica.

65. KROPF, Rudolf; POLSTER, Gert (eds.) - Andreas Baumkircher und das ausgehende Mittelalter. Tagungsband der 32. Schlaininger Gespräche 16. bis 20. September 2012. Eisenstadt: Landesmuseum 2015; KROPF, Rudolf (ed.) - Andreas Baumkircher. Leben und Sterben im 15. Jahrhundert. Eisenstadt: Burgenländischen Landesregierung, 2013 (Wissenschaftliche Arbeiten aus dem Burgenland 144); Andreas Baumkircher und seine Zeit. Eisenstadt: Burgenländisches Landesmuseum, 1983 (Wissenschaftliche Arbeiten aus dem Burgenland 67).

66. Millstatt, Mailberg, the hospital of St. Martin in the suburbs of Vienna, the chapel of St. Mary at Neustift (near Obernburg, Gornji Grad, in Styria), the parish church St. Mary at Straden (near Mureck, Cmurek, in Styria): Monumenta Ducatus Carinthiae ..., pp. 160-164 n. 406.

67. Slovene: Celje. On the archives of Millstatt, LATZKE, Wilhelm - "Die Klosterarchive". in BITTNER, Ludwig (ed.) - Gesamtinventar des Wiener Haus-, Hof- und Staatsarchivs, Teil 3, ed. Wien, 1938, pp. 583-616.

68. 1479 June 24 and 1480 August 5: Repertorium Germanicum X ..., n. 7968.

69. BUTTLAR-GERHARTL, Gertrud - "Der St. Georgs-Ritterorden und Wiener Neustadt". in NIKOLASCH, Franz (ed.) - Studien zur Geschichte von Millstatt und Kärnten, Vorträge der Millstätter Symposien 1981 bis 1995. Klagenfurt: Habelt, 1997, pp. 511-527.

70. NEHRING, Karl - Matthias Corvinus, Kaiser Friedrich III. und das Reich. Zum hunyadischhabsburgischen Gegensatz im Donauraum. München: R. Oldenbourg, 1975 (Südosteuropäische Arbeiten 72), pp. 20-23, pp. 202-217, with an edition of the documents from 1463/64.

71. 1481: DAUBER, Robert L. - Die Johanniter-Malteser ..., vol. 2, p. 583. Auer is mentioned by HEINIG, Paul-Joachim - Kaiser Friedrich III ..., vol. 3, p. 1391 as being in office as chamberlain from 1474/79-93. The Auer were knights, former ministeriales of the bishops of Gurk: WIESSNER, Hermann - Die Schenken von Osterwitz ..., pp. 110-11 ns. 407, 411. 
72. 1481 October 1 to Peter Knauer, Provost of Laibach: PETERSOHN, Jürgen - “... quod sanctitas sua in auxilium brachii secularis maiestati sue firmiter adhereat. Politische Zielvorstellungen Kaiser Friedrichs III. für ein Hilfsbündnis mit Papst Sixtus IV”. in FUCHS, Franz; HEINIG, Paul-Joachim; SCHWARZ, Jörg - König, Fürsten und Reich im 15. Jahrhundert. Köln: Böhlau, 2009 (Forschungen zur Kaiser- und Papstgeschichte des Mittelalters, Beihefte zu J. F. Böhmer, Regesta Imperii 29), pp. 123-141, here pp. 138,141 note 20.

73. Czech: Jan ze Švamberka.

74. Repertorium Germanicum X ..., n. 2500.

75. 1483 April 14: Repertorium Germanicum X ..., n. 1259.

76. 1483 November 28 and December 5: Repertorium Germanicum X ..., ns. 1259, 2626, Plestet erroneously for Flestet.

77. Rome at St. Peter's, 1484 October 30 and November 4: Prague, Národní archiv, Maltézští rytíri - české velkopřevorství n. 1479, an authenticated copy from Buda, 1486 April 13.

78. RÁzSÓ, Gyula - Die Feldzüge des Königs Matthias Corvinus in Niederösterreich 1477-1490. $3^{\text {rd }}$ ed. Wien: Österreichischer Bundesverlag,1982 (Militärhistorische Schriftenreihe 24); WOLF, Susanne - Die Doppelregierung Kaiser Friedrichs III. und König Maximilians (1486-1493). Köln-Weimar-Wien: Böhlau, 2005 (Forschungen zur Kaiser- und Papstgeschichte des Mittelalters 25), pp. 148-182; HOENSCH, Jörg K. - Matthias Corvinus. Diplomat, Feldherr und Mäzen. Graz-Wien-Köln: Styria, 1998, pp. 183-198, pp. 206-215, pp. 217-218; CSENDES, Peter; OPLL, Ferdinand (eds.) - Wien. Geschichte einer Stadt ..., pp. 168-177.

79. 1486 December 18, a declaration by Auer that mentioned Fr. Kaspar Haugwitz as procurator of Mailberg, commanders and other Hospitallers in the Bailiwick of Austria, Styria, Carinthia and Carniola: Regesten Kaiser Friedrichs III. (1440-1493): nach Archiven und Bibliotheken geordnet H. 30. Ed. Peter Gretzel. Wien-Köln-Weimar: Böhlau, 2014, pp. 166-168, ns. 247-49.

80. DAUBER, Robert L. - Die Johanniter-Malteser ..., vol. 2, p. 538.

81. WOLF, Susanne - Die Doppelregierung..., pp. 252-272; WIESFLECKER, Hermann - Kaiser Maximilian I. Das Reich, Österreich und Europa an der Wende zur Neuzeit. 5 vols. München: Oldenbourg, 1971-1986, vol. 1, pp. 271-308.

82. DAUBER, Robert L. -Die Johanniter-Malteser ..., vol. 2, p. 583.

83. Breda, 1495 February 9: Regesta Imperii XIV,1 n. 1326; HEINIG, Paul-Joachim - Kaiser Friedrich III..., vol. 1, p. 413.

84. DAUBER, Robert L. - Die Johanniter-Malteser ..., vol. 2, p. 583.

85. Vienna, 1496 July 20: Regesta Imperii XIV, 2, n. 7187.

86. Czech: Jan z Rožmberka.

87. Baden, 1503 June 19: Regesta Imperii XIV, 4, 2, n. 20525. Wok von Rosenberg added that he hoped his son would succeed the present master of Strakonitz, that is the Prior of Bohemia. In fact Fr. Johann von Rosenberg became Prior of Bohemia in 1517 and died in 1532: KOTLÁROVÁ, Simona - Jan III. $z$ Rožmberka: 1484 - 1532: generální převor johanitského řádu $v$ Čechách a vladar̆ rožmberského domu. Vyd. 1. České Budějovice: Veduta, 2010 (Osobnosti českých a moravských dějin 9).

88. Augsburg, 1503 November 15: Regesta Imperii XIV, 4, 1, n. 17911.

89. Augsburg, 1503 November 22: Regesta Imperii XIV, 4, 1, ns. 17933, 17934, 17936. See also Augsburg, 1503 November 27: Regesta Imperii XIV, 4, 1, n. 17942.

90. Augsburg, 1504 March 29: Regesta Imperii XIV, 4, 1, n. 18471. Augsburg, 1504 April 14: Regesta Imperii XIV, 4, 1 n. 18562. Innsbruck, 1504 June 12: Regesta Imperii XIV, 4, 1, n. 18861. DAUBER, Robert L. - Die Johanniter-Malteser ..., vol. 2, p. 583.

91. DAUBER, Robert L. - Die Johanniter-Malteser ..., vol. 2, p. 584. 1510 November 6: Prague, Národní archiv, Maltéžstí rytíríi - české velkopřevorství n. 1496. This document called Peter Moragsky master and knight, but not frater of the Hospital. 
92. Salzburg, 1504 December 18: Regesta Imperii XIV, 4, 1 n. 19489. Johann Maraxi, his wife, his cousin Peter and their male heirs got a house in Vienna, either the one in which so far Count Philipp of Nassau had lived or another one.

93. Rhodes, 1512 September 18: Prague, Národní archiv, Maltézští rytíři - české velkopřevorství n. 1489.

94. WIESFLECKER, Hermann - Kaiser Maximilian ..., vol. 4, pp. 162-221.

95. DAUBER, Robert L. - Die Johanniter-Malteser ..., vol. 2, p. 584.

96. WIESFLECKER, Hermann - Kaiser Maximilian ..., vol. 4, pp. 446-453.

97. JANKO, Wilhelm Edler von - "Ebersdorf, Reinprecht von". Allgemeine Deutsche Biographie [On line] 5 (1877), pp. 578-579. [accessed at 25 November 2020]. Available at https://www.deutschebiographie.de/pnd13573522X.html.

98. Czech: Berka z Dubé a Lipa.

99. DAUBER, Robert L. - Die Johanniter-Malteser ..., vol. 2, p. 475. French: Bollwiller near Mülhausen, Mulhouse in Alsace.

100. For the priory of Catalonia see BONNEAUD, Pierre - Le prieuré de Catalogne, le couvent de Rhodes et la couronne d'Aragon: 1415-1447. Millau: Conservatoire Larzac, 2004 (Milites Christi 2); BONNEAUD, Pierre - Els hospitalers catalans a la fi de l'edat mitjana: l'orde de l'Hospital a Catalunya i a la Mediterrània, 1396-1472. Lleida: Pagès, 2008 (Els ordes militars 11).

101. KAPP, Daniel - “Der Orden von 1938 bis 1945: Zwischen Anpassung auf Auflösung”. in STEEB, Christian; STRIMITZER, Birgit (eds.) - Der Souveräne Malteser-Ritter-Orden in Österreich. Graz: Leykam, 1999, pp. 241-249.

102. Editorial principles: Names are rendered as in the charter. Otherwise, the usual scribal conventions permit normalisations, for example $u$ and $v$ according to their pronunciation, $j$ always being $i$, ff at the beginning of a word being reduced to $f$.

103. Senk meaning Šenk Czech orthography for Schenk

104. Abbreviation $q^{\circ}$ plus -(us) or -(con), -(cum), either quocumque (with -que missing) or quominus.

105. Ivanovice na Hané in Moravia.

106. Rokitzan in Bohemia.

107. In Styria.

108. In Styria near Fürstenfeld.

109. Unterlaa near Vienna.

110. In Styria, Melje, near Maribor, Marburg an der Drau, today in Slovenia.

111. Šempeter na Krasu, Šentpeter na Krasu, San Pietro del Carso, today Pivka in Slovenia.

112. Orlovice, in Moravia.

113. Wrocław, in Silesia.

114. Brzeg, in Silesia.

115. Kadaň, in Bohemia.

116. Żytawa, Žitava, in Lusatia.

117. Groß Tinz an der Lohe, Tyniec nad ŚlĘżĄ, in Silesia.

118. The Master of the Order from Rhodes.

119. Mladá Boleslav, in Bohemia.

120. Straconice, in Bohemia.

121. Český Dub, Böhmisch Aicha, in Bohemia.

122. Kłodzko, Kladsko, in Bohemia, today in Silesia.

123. Lwówek Śląski, in Silesia.

124. Złotoryja, in Silesia.

125. Today Dzierżoniów, in Silesia.

126. Strzegom, in Silesia.

127. Oleśnica Mała, in Silesia.

128. Zawadno, in Silesia. 
129. Głubczyce, Hlubčice, in Silesia.

130. Opava, Opawa, in Silesia.

131. Koźle, in Silesia.

132. Maków, in Silesia.

133. Kroměříž, in Moravia.

134. Brno, in Moravia.

135. Oberkaunitz, Horní Kounice, in Moravia.

136. Brtnice, in Moravia.

137. In this case the leading or senior priest of the house.

138. Erdberg, Hrádek u Znojma, in Moravia.

\section{ABSTRACTS}

The medieval Hospitaller priory of Bohemia was riven by ethnic divisions and mutually unintelligible languages. The prior's lieutenant for Austria, Styria, Carinthia and Carniola, who often resided at the important commandery of Mailberg, could have been a nucleus for Austrian independence from Bohemia. The paper edits and discusses a document from 1392 where the prioral chapter deals with a quarrel between Hospitallers in Austria and Styria; their fellowHospitallers from the lands of the Bohemian crown (Bohemia proper, Moravia, Silesia) carefully avoided to be offend Duke Albert III of Austria. In the following decades tensions between two rival Habsburg lines in Austria and Styria weakened the position of the Hospitaller lieutenants for the Habsburg lands, especially during the Hussite wars. After the reunification of the Habsburg lands in the early 1460s the commandery of Mailberg was given by Emperor Frederick III and his son Maximilian to their courtiers and creditors, some of whom were not even Hospitallers. With papal support Frederick III tried to transfer Mailberg to his newlyfounded military-religious order of St. George at Millstatt in Carinthia. But when the Habsburg rulers became kings of Bohemia and Hungary in 1526, they ceased to be interested in splitting up the Hospitaller priory of Bohemia. In the early modern period this proved to be more important for the future of the priory than "proto-national" identities.

O Priorado do Hospital na Boémia medieval, com sede em Praga, estava fragmentado por divisões étnicas e por línguas mutuamente ininteligíveis. O lugar-tenente do prior para a Áustria, Estíria, Caríntia e Carniola, que muitas vezes residia na importante comenda de Mailberg, poderia ter constituído o núcleo para a separação da Áustria relativamente à Boémia. Neste artigo edita-se e discute-se um diploma de 1392, com a resolução do capítulo do Priorado sobre a disputa entre os Hospitalários da Áustria e da Estíria, no qual os hospitalários das terras da coroa da Boémia (Boémia propriamente dita, Morávia, Silésia) evitaram cuidadosamente ofender o duque Alberto III da Áustria. Nas décadas seguintes, as tensões entre as linhas rivais dos Habsburgos na Áustria e na Estíria enfraqueceram a posição dos lugares-tenentes do Hospital, em particular durante as guerras hussitas. Após a reunificação das terras dos Habsburgos no início da década de 1460, Mailberg foi dada pelo imperador Frederico III e pelo seu filho Maximiliano a cortesãos e a credores, alguns dos quais nem sequer eram freires do Hospital. Com o apoio papal, Frederico III tentou transferir Mailberg para sua recém-fundada Ordem religiosa-militar de São Jorge, sediada em Millstatt, na Caríntia. Mas quando os Habsburgos se tornaram reis da Boémia e da Hungria em 1526, deixaram de se interessar pela divisão do Priorado do Hospital da Boémia. No início da 
época moderna, isso seria mais importante para o futuro do Priorado do que as identidades "protonacionais".

INDEX

Keywords: Hospitallers, Bohemia, Austria, Mailberg, Emperor Frederick III

Palavras-chave: Hospitalários, Boémia, Áustria, Mailberg, Imperador Frederico III

\section{AUTHOR}

\section{KARL BORCHARDT}

Monumenta Germaniae Historica, Munich. karl.borchardt@mgh.de 